\title{
Tracing anthropogenic sources of Tantalum and Niobium in Bothnian Bay sediments, Sweden
}

\author{
S Sutliff-Johansson ${ }^{1} \cdot$ S Pontér $^{1} \cdot$ E Engström $^{1,2} \cdot$ I Rodushkin $^{1,2} \cdot$ P Peltola $^{3} \cdot$ A Widerlund $^{1}$
}

Received: 3 September 2020 / Accepted: 29 November 2020 / Published online: 9 December 2020

(C) The Author(s) 2020

\begin{abstract}
Purpose This study aims to evaluate temporal trends of Tantalum (Ta) and Niobium (Nb) concentrations in northern Baltic Sea sediments with focus on the potential impact from the Rönnskär sulfide ore smelter, located $15 \mathrm{~km}$ east of Skellefteå in northern Sweden. The potential of $\mathrm{Ta}$ or $\mathrm{Nb}$ to serve as tracers for environmental pollution caused by the electronic waste is compared. Lastly, correlations between $\mathrm{Ta}$ and $\mathrm{Nb}$ concentrations and those of major redox elements are investigated.

Methods A 35-cm-deep core was collected in the harbor bay (Kallholmsfjärden) outside of the smelter. A secondary 6-m-deep sediment core was collected in the deep Bothnian Bay for comparative purposes. Element screening analysis was conducted the using ICP-SFMS for the Kallhomsfjärden core and a combination of ICP-SFMS and ICP-OES for the Bothnian Bay core. In the final analysis, a 5-step sequential extraction technique was preformed to allow for better prediction of the fate and mobility of Ta and $\mathrm{Nb}$.

Results and discussion In the vicinity of the smelter, Ta concentration increases from 0.42 to $3.8 \mathrm{ppm}$ from the time coinciding with the beginning of electronic waste processing. Conversely, $\mathrm{Nb}$ concentration remained stable at background levels throughout the core at $6.33 \pm 0.78 \mathrm{ppm}$. The $\mathrm{Nb} / \mathrm{Ta}$ ratio thus changed from 14.5 to 1.7 , reflecting an increase of anthropogenic input of $\mathrm{Ta}$ into the bay sediments. In the pre-industrial part of the sediment, concentrations of both elements follow concentration of aluminosilicates in the core. In recent sediments, however, the anthropogenic Ta exhibits an association with hydrous ferric oxides (HFOs) and organic matter.

Conclusions Notable increases in Ta concentrations began following the beginning of scrap metal and electronic waste processing at the Rönnskär smelter. Anthropogenic Ta introduced in the upper portion of the sediment and are more associated with HFOs and organic material than natural Ta seen in the deeper parts of the core where detrital Ta is most common. Niobium was not affected by the Rönnskär smelter and displayed no notable change to the preindustrial background.
\end{abstract}

Keywords Technology-critical elements $\cdot$ Industrial smelter $\cdot$ Niobium $\cdot$ Tantalum $\cdot$ Contamination $\cdot$ Sediment

\section{Introduction}

Tantalum (Ta) and Niobium $(\mathrm{Nb})$ form complexes with several oxidation states of $+2,+3,+4$, and +5 ; however, the +5 oxidation state is the most stable and the only one found in

Responsible editor: Patrick Byrne

S Sutliff-Johansson

Stacy.Sutliff-Johansson@1tu.se

1 Division of Geosciences and Environmental Engineering, Luleå University of Technology, SE-971 87 Luleå, Sweden

2 ALS Scandinavia AB, Aurorum 10, SE-977 75, Luleå, Sweden

3 Boliden Rönnskär, SE-932 81, Skelleftehamn, Sweden nature. Most studies focusing on $\mathrm{Ta}$ and $\mathrm{Nb}$ are largely based on their mineralogy due to their economic importance in the electronics and steel industries (Cerny and Ercit 1989; Selway et al. 2005; Ghorbani et al. 2017; Melcher et al. 2017a, b). Tantalum and $\mathrm{Nb}$ are lithophile elements and occur almost exclusively in oxide and hydroxide minerals. They are known to form rare minerals such as pyrochlore $(\mathrm{Na}, \mathrm{Ca})_{2}(\mathrm{Nb}, \mathrm{Ta})_{2} \mathrm{O}_{6}(\mathrm{OH}, \mathrm{F})$, tantalite $(\mathrm{Fe}, \mathrm{Mn})(\mathrm{Ta})_{2} \mathrm{O}_{6}$, and columbite $(\mathrm{Fe}, \mathrm{Mn})(\mathrm{Ta})_{2} \mathrm{O}_{6}$, but can also be found in trace levels in rock-forming minerals such as biotite, rutile, sphene, and zircon (Salminen et al. 2005). Both $\mathrm{Ta}$ and $\mathrm{Nb}$ are also often produced as a byproduct of tin mining due to their presence in cassiterite $\left(\mathrm{SnO}_{2}\right)$. Aided by the improvement in analytical methods, estimation of $\mathrm{Ta}$ and $\mathrm{Nb}$ abundances in the upper continental crust (UCC), needed for better 
understanding mass balances of the Earth (Filella 2017), has gained renewed interest in recent years. Previous UCC abundances for $\mathrm{Ta}(2 \mathrm{ppm})$ and $\mathrm{Nb}(20 \mathrm{ppm})$ originate from the work of Rankama (1944) and was confirmed by Taylor and McLennan (1985). However, more recent studies suggest the UCC abundance of Ta being around $0.92 \pm 0.2 \mathrm{ppm}, \mathrm{Nb}$ at 12 \pm 2 ppm, with a $\mathrm{Nb} / \mathrm{Ta}$ ratio of around 12 (Gallet et al. 1998; Plank and Langmuir 1998; Barth et al. 2000; Emsley 2001; $\mathrm{Hu}$ and Gao 2008; Rudnick and Gao 2013). Niobium and Ta have long been regarded as "geochemical twins." They exhibit a strong geochemical coherence due to their similar ionic radii $(\mathrm{Nb}=215 \mathrm{pm}, \mathrm{Ta}=220 \mathrm{pm})$ and prevailing valence state. Researchers have linked specific ratios between these two elements to certain cosmological and geological processes (Taylor and McLennan 1985; Plank and Langmuir 1998; Barth et al. 2000; Xiao et al. 2006; Rudnick and Gao 2013; Cartier et al. 2014; Filella 2017; Melcher et al. 2017a). However, due to their generally low concentrations, to the best of our knowledge, this ratio is yet to be used as pollution tracer in the environment.

Though few studies report on $\mathrm{Ta}$ and $\mathrm{Nb}$ concentrations in sediments (Chandrajith et al. 2001; Selway et al. 2005; Viers et al. 2009; Cartier et al. 2014), there is limited information on the relationships between $\mathrm{Ta}$ and $\mathrm{Nb}$ and important metal carrier phases such as organic matter and Fe and $\mathrm{Mn}$ oxyhydroxides. In a Forum of European Geological Surveys (FOREGS) report on Ta, it was suggested that there is a possibility that Ta may form complexes with organic material in aqueous systems as it has been shown that it will form watersoluble complexes with carboxylic hydroxyacids and oxalic acids (Fairbrother 1967; Ciaravino et al. 2002; Salminen et al. 2004). In a study by Åström et al. (2008) focusing on nondetrital $\mathrm{Nb}$ in boreal stream waters and brackish-water/lacustrine sediments, the main transport mechanism of $\mathrm{Nb}$ in stream waters was linked to dissolved humic substances and colloidal Fe-oxyhydroxides mixed with organic compounds. In another study by Koschinsky and Hein (2003), sequential leaching of Fe-Mn oxyhydroxide crusts showed that Ta was bound to the Fe-oxyhydroxides and not to the Mn-oxides. Although it is believed that due to the stability of their oxide phases both $\mathrm{Ta}$ and $\mathrm{Nb}$ display low mobility under most environmental conditions, these studies show that in certain conditions, their abundance and transport in the aquatic systems may increase.

The use of $\mathrm{Ta}$ and $\mathrm{Nb}$ in consumer electronics and industrial materials is likely to result in higher anthropogenic input of these two elements. Though $\mathrm{Ta}$ and $\mathrm{Nb}$ are chemically similar, they are often used for different purposes in today's society. Tantalum is mainly used in electronic components such as capacitors, high-power resistors, and wiring, while $\mathrm{Nb}$ is primarily used as an alloying element in stainless-steel and other nonferrous metals. Both are considered as emerging contaminants belonging to the group of technologically critical elements (TCEs) characterized by their increased use in the modern technological applications and the lack of their current recyclability (Gunn 2014; Filella 2017). Presently, dated sediment core profiles with $\mathrm{Ta}$ and $\mathrm{Nb}$ values of high analytical quality are limited, and those that do exist often show only the speciation and background concentrations of naturally occurring $\mathrm{Ta}$ and $\mathrm{Nb}$.

With the expected increase of anthropogenic release of Ta and $\mathrm{Nb}$ into the environment, a better understanding of their geochemical behavior in natural systems is needed. The hypothesis of this study is that (1) anthropogenic release of Ta and/or $\mathrm{Nb}$ may change the natural covariation of $\mathrm{Ta}$ and $\mathrm{Nb}$ normally observed in rocks, soils, and sediments, and (2) that Fe-oxyhydroxides in Bothnian Bay sediments may act as a carrier for anthropogenically released $\mathrm{Ta}$ and/or $\mathrm{Nb}$.

The objectives of this study were to (1) investigate historical changes in $\mathrm{Ta}$ and $\mathrm{Nb}$ concentrations and the $\mathrm{Nb} / \mathrm{Ta}$ ratio in coastal sediments, (2) estimate a long-term average of Ta and $\mathrm{Nb}$ concentrations in pre-industrial, post-glacial sediments dating back to approximately $7000 \mathrm{BP}$, and (3) study the association of $\mathrm{Ta}$ and $\mathrm{Nb}$ with Fe-oxyhydroxides as Bothnian Bay sediments in Northern Sweden are known for well-developed Fe-oxyhydroxide layers buried in anoxic sediment (Ingri and Pontér 1986; Widerlund and Ingri 1996). A sediment core was collected in the vicinity of the Rönnskär sulfide ore smelter in Northern Sweden where large amounts of electronic scrap are processed. Using this core, recent temporal trends of $\mathrm{Ta}$ and $\mathrm{Nb}$ concentrations in sediments are evaluated, and the $\mathrm{Nb} / \mathrm{Ta}$ ratio is tested as a potential tracer for pollution caused by electronic waste processing.

\section{Site description}

The Bothnian Bay is the northernmost sub-basin of the Baltic Sea (Fig. 1), and is surrounded by Proterozoic and Archean rocks of predominantly granodioritic composition, similar in chemical composition to the upper continental crust (UCC) (Gaál and Gorbatschev 1987; Rudnick and Gao 2013). The open Bothnian Bay is predominantly characterized by accumulation bottoms at water depths exceeding 40-75 m (Brydsten 1993), where undisturbed laminated postglacial silt and clay are common (Voipio 1981). Lamination of sediments, suggesting undisturbed conditions with little or no bioturbation are also observed in coastal areas (Widerlund and Roos 1994). These laminated sediments often contain buried Fe-oxyhydroxide layers that occur below the Fe-Mn redox boundary in the suboxic and anoxic parts of the sediments (Ingri and Pontér 1986; Widerlund and Roos 1994). In the following, poorly crystalline hydrous ferric oxides of undefined composition are referred to as HFO.

The Skellefteå harbor is a commercial port located $15 \mathrm{~km}$ east of the town of Skellefteå, on the Bothnian Bay shore (Fig. 1). The harbor bay (Kallholmsfjärden) has an area of around 2 


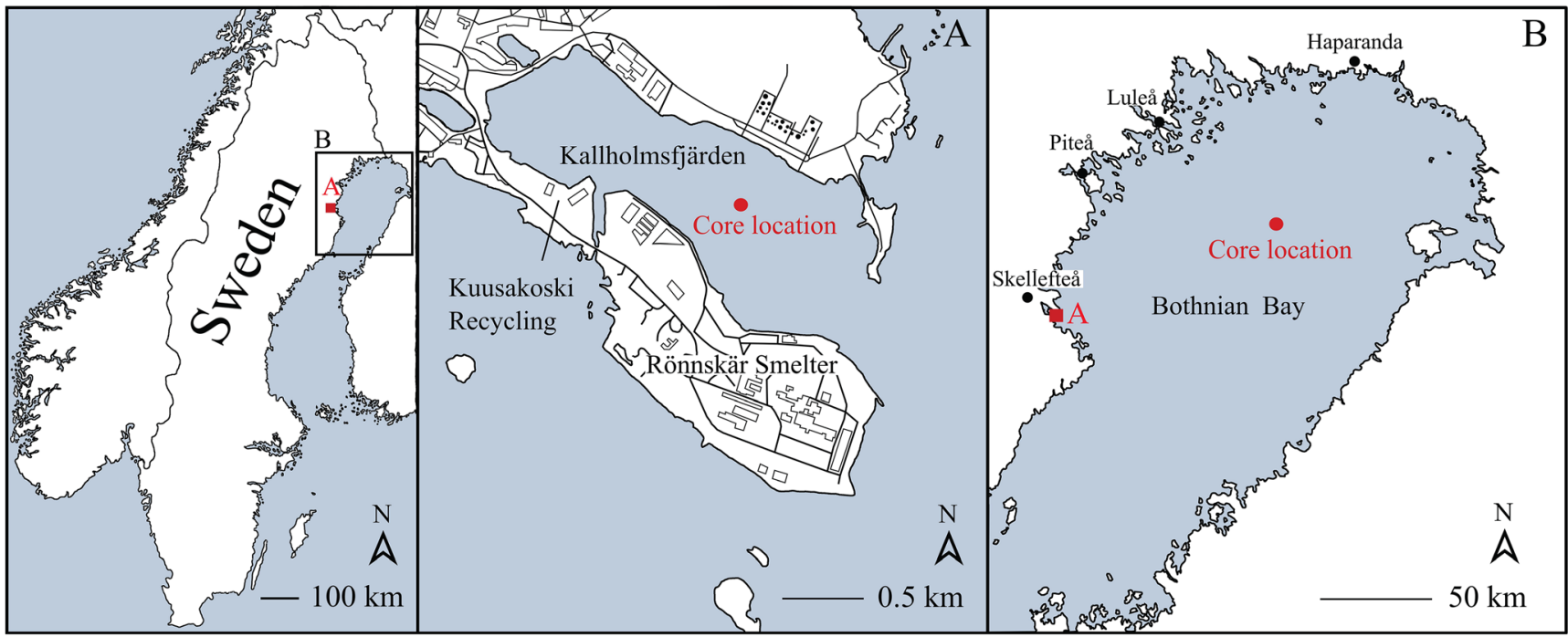

Fig. 1 Location of the study areas in the Bothnian Bay, northern Sweden. a Location of Kallholmsfjärden core sampling site. b Location of Bothnian Bay core sampling site

$\mathrm{km}^{2}$, a maximum water depth of $20 \mathrm{~m}$, and a turnover time of $\leq 9$ days (Viss 2017). There are no streams flowing into the bay and the water is low-saline $(\leq 3 \mathrm{psu})$ brackish water from the Baltic Sea (Voipio 1981; Sobek et al. 2012). The bay is partially protected by an island shield, which results in eroded sediment accumulating in the bay with little re-suspension and transport.

\subsection{Industrial history}

The Skellefteå harbor was originally constructed in 1913 for the transport of bitumen. This location was chosen by Boliden Mineral $\mathrm{AB}$ for a $\mathrm{Cu}-\mathrm{Pb}-\mathrm{Zn}$ smelter which they began constructing in 1928. The smelter originally aimed at processing the complex Boliden Cu-As-Au ore from the Skellefte Sulfide Ore District, which was difficult to refine in ordinary smelters due to the high As content. The location for the Rönnskär smelter was chosen to optimize transport of refined ore from the mine, and to limit acute environmental damage of the surrounding area. The smelter was built on the two islands of Hamnskär and Rönnskär, which were later combined and joined with the mainland using a granulated slag called Iron Sand. A 145-m-tall central chimney was constructed at the smelter so that ash, sulfur dioxide, and other airborne pollutants produced from the refining process would mainly spread out into the Bothnian Bay. Wastewater generated during smelting was also discharged into the Bothnian Bay until 1970 when water treatment was introduced.

Production began in 1930 with a singular focus on $\mathrm{Au}$ and $\mathrm{Cu}$ ore from the Boliden mine. During the 1940s, Rönnskär shifted emphasis from $\mathrm{Au}$ to $\mathrm{Cu}, \mathrm{Ni}$, and $\mathrm{Pb}$ to supply a demand generated during World War II. Zinc and scrap metal processing were added to the production line in the 1960s. In 1980 , Boliden began to process electronic scrap to aid in the increasing demand for $\mathrm{Cu}$ and $\mathrm{Au}$. Scrap metal and electronic waste became more important in Rönnskär's production line in the following years. In 2002, Kuusakoski Recycling Company situated at the Skellefteå harbor began to preprocess the electronic waste to be sent to Rönnskär for recycling. By 2004, 40\% of $\mathrm{Au}$ and $20 \%$ of $\mathrm{Cu}$ produced at Rönnskär was from recycled scrap materials (Nyström 2004). Boliden later tripled their electronic waste production in 2012 from 45,000 to 120,000 t of recycled electronic scrap per year with the introduction of the Kaldo furnace.

Prior to the Environmental Protection Act of 1969 (Bergquist 2007; Sobek et al. 2012), large amounts of sulfur dioxide and heavy metals were released into the environment. Since the 1970s, Boliden Mineral AB has drastically decreased the emissions to air and water by processing sulfur dioxide into sulfuric acid and implementing filters to collect ash from the fumes.

\section{Methods}

\subsection{Field sampling}

\subsubsection{Kallholmsfjärden core}

A 35-cm-deep core was collected in June of 2017 with a modified Kajak gravity corer with a core tube diameter of $6.4 \mathrm{~cm}$ (Blomqvist and Abrahamsson 1985). Location for the core was chosen at the deepest part of the harbor bay at $\mathrm{N} 64^{\circ} 40.553^{\prime}$, E $21^{\circ} 16.189^{\prime}$ at a depth of $16 \mathrm{~m}$ (Fig. 1). The core was divided in the field into $0.5 \mathrm{~cm}$ subsamples between the top $0-5 \mathrm{~cm}$; this was followed by $1 \mathrm{~cm}$ subsamples from 5 to $15 \mathrm{~cm}$, and lastly, $2 \mathrm{~cm}$ subsamples from 15 to $35 \mathrm{~cm}$. 


\subsubsection{Bothnian Bay cores}

In September of 2009, a 6-m-deep sediment core was collected in the open Bothnian Bay (N $\left.65^{\circ} 11.46^{\prime}, \mathrm{E} 23^{\circ} 23.80^{\prime}\right)$ at a water depth of $89 \mathrm{~m}$ (Fig. 1). The core was collected from the Swedish Geological Survey research vessel S/V Ocean Surveyor using a Kullenberg piston corer with a diameter of $6.6 \mathrm{~cm}$ (Ingri et al. 2014). Sediment subsamples were taken every $3 \mathrm{~cm}$ throughout the core. In addition, to get a better spatial resolution at the sediment surface, a 1-m-deep core was also collected at the same site using a Gemini gravity corer. In this core, $1 \mathrm{~cm}$ subsamples were analyzed in the top $16 \mathrm{~cm}$.

\subsection{Analytical procedures}

\subsubsection{Kallholmsfjärden core}

Sediment samples were dried in an oven at $50{ }^{\circ} \mathrm{C}$ overnight and then lightly grinded using a mortar and pestle. Samples were prepared and analyzed by the accredited laboratory ALS Scandinavia AB in Luleå, Sweden. Before use, all laboratory materials were soaked in $0.7 \mathrm{M} \mathrm{HNO}_{3}$ (sp grade) for $24 \mathrm{~h}$ at room temperature and rinsed with Milli-Q water. Detailed descriptions of all precautions taken to minimize contamination are presented and discussed by Rodushkin et al. (2010). Sediments were weighed to $50 \mathrm{mg}$ and placed into $60 \mathrm{ml}$ conical polypropylene centrifuge tubes. Digestion was achieved with the addition of $5 \mathrm{ml}$ concentrated $\mathrm{HNO}_{3}$ (sp grade), $4 \mathrm{ml} \mathrm{HCl}$ (sp grade), and $0.5 \mathrm{ml} \mathrm{HF}$ (sp grade) added to each sample. Samples were subsequently placed in a heating block for one hour. An addition of $1 \mathrm{ml} \mathrm{HNO}_{3}$ (sp grade) was used to wash down solid material adhering to the sides of the container following agitation to ensure complete digestion. Digests were diluted with $1.4 \mathrm{M} \mathrm{HNO}_{3}$ (sp grade) to final volume providing the total dilution factor of approximately $4000(\mathrm{~m} / \mathrm{v})$. All measuring solutions were spiked with internal standard (In) at $50 \mu \mathrm{g} \mathrm{L}^{-1}$, and concentrations of approximately 70 elements were measured by inductively coupled plasma-sector field mass spectrometry (ICP-SFMS, ELEMENT2, ThermoScientific, Bremen, Germany) using a combination of internal standardization and external calibration.

Two stream sediment certified reference materials (GBW07306 and GBW07311, National Research Centre for Certified Reference Materials, China) were used to estimate accuracy of analytical methods and measured concentrations agreed with target values within 15\% RSD for all analytes (Table 1).

\subsubsection{Bothnian Bay cores}

Dried sediment samples were prepared using a combination alkali fusion followed by major element determination using inductively coupled plasma-optical emission spectrometry (ICP-OES, ARL3560) and MW-assisted closed-vessel acid digestion (mixture of $5 \mathrm{ml} \mathrm{HNO}_{3}$ and $1 \mathrm{ml}$ of $\mathrm{HF}$ per $100 \mathrm{mg}$ of sample) followed by determination of sulfur, minor, and trace elements by ICP-SFMS as described in Ödman et al. (1999).

Stream sediment certified reference material (NCSDC73308, National Research Centre for Certified Reference Materials, China) was used to estimate accuracy of analytical methods and measured concentrations agreed with target values within 15\% RSD for all analytes (Table 1).

\subsection{Sequential leaching}

A 5-step sequential extraction was conducted to determine the partitioning of particulate trace metals into the following fractions: (1) adsorbed and exchangeable metals and carbonates, (2) labile organic forms, (3) amorphous Fe/Mn oxides, (4) crystalline Fe-oxides, and (5) stabile organic forms and sulfides. The procedure use for the extraction was a modified version of the method presented in Hall et al. (1996) and Land et al. (1999b). The procedures involved in each of the steps with regards to $1 \mathrm{~g}$ of sample are as follows:

1. Adsorbed and exchangeable fraction - one gram of sample and $10 \mathrm{ml}$ of $1.0 \mathrm{M} \mathrm{CH}_{3} \mathrm{COONa}$ at $\mathrm{pH} 5$ was added to a centrifuge tube. This was then subjected to continuous agitation for $6 \mathrm{~h}$ and subsequently centrifuged for $15 \mathrm{~min}$ at $3000 \mathrm{rpm}$. The supernatant was then decanted into a new test-tube. This step was done twice. The residue was then rinsed with $5 \mathrm{ml}$ Milli-Q water, centrifuged, and the supernatant added to the test-tube.

2. Labile organic forms - the residue from the previous step (1) was leached with $50 \mathrm{ml}$ of $0.1 \mathrm{M} \mathrm{Na}_{4} \mathrm{P}_{2} \mathrm{O}_{7}$. This was then followed by $1 \mathrm{~h}$ of continuous shaking and centrifugation. The supernatant was decanted into a new test tube. This step was then repeated. The residue was then rinsed with $5 \mathrm{ml}$ Milli-Q water, centrifuged, and the supernatant added to the test-tube.

3. Amorphous $\mathrm{Fe} / \mathrm{Mn}$ oxides $-1 \mathrm{ml}$ of $0.25 \mathrm{M} \mathrm{NH}_{2} \mathrm{OH} \cdot \mathrm{HCl}$ in $0.1 \mathrm{M} \mathrm{HCl}$ was added to the residue from the previous step (2). The sample was placed in a water bath at $60{ }^{\circ} \mathrm{C}$ for $2 \mathrm{~h}$ and then subsequently centrifuged. The supernatant was then decanted into a new test tube. These steps repeated twice. The residue was then rinsed with $5 \mathrm{ml}$ Milli-Q water, centrifuged, and the supernatant added to the test-tube.

4. Crystalline $\mathrm{Fe}$-oxides - the residue from step 3 was leached with $15 \mathrm{ml}$ of $1.0 \mathrm{M} \mathrm{NH}_{2} \mathrm{OH} \cdot \mathrm{HCl}$ in $25 \%$ $\mathrm{CH}_{3} \mathrm{COOH}$ at $90^{\circ} \mathrm{C}$. The sample was warmed in a water bath at $90^{\circ} \mathrm{C}$ for $3 \mathrm{~h}$ and centrifuged. The supernatant was decanted into a new test tube. This step was then repeated with the exception that the heating time was decreased to 
Table 1 Limit of detection and certified reference materials for estimation of accuracy for the analytical methods and measured concentrations in the Kallholmsfjärden core and the Bothnian Bay Cores.

\begin{tabular}{|c|c|c|c|c|c|c|c|c|c|c|}
\hline & \multirow{4}{*}{$\begin{array}{l}\text { Limit of detection } \\
\mathrm{mg} \mathrm{kg}^{-1}\end{array}$} & \multicolumn{9}{|c|}{ Certified reference materials } \\
\hline & & \multicolumn{6}{|c|}{ Kallholmsfjärden core } & \multirow{2}{*}{\multicolumn{3}{|c|}{$\frac{\text { Bothnian Bay cores }}{\text { NCSDC73308 }}$}} \\
\hline & & \multicolumn{3}{|c|}{ GBW07306 } & \multicolumn{3}{|c|}{ GBW07311 } & & & \\
\hline & & Found & $\mathrm{SD}$ & $\begin{array}{l}\text { Certified/ } \\
\text { published }\end{array}$ & Found & SD & $\begin{array}{l}\text { Certified/ } \\
\text { published }\end{array}$ & Found & $\mathrm{SD}$ & $\begin{array}{l}\text { Certified/ } \\
\text { published }\end{array}$ \\
\hline $\mathrm{Al}$ & 2 & 73,600 & 2300 & 75,000 & 51,100 & 1330 & 52,700 & 14,271 & 1511 & 28,400 \\
\hline $\mathrm{Fe}$ & 0.5 & 54,700 & 1710 & 53,400 & 31,600 & 1120 & 30,700 & 26,890 & 1435 & 386,000 \\
\hline $\mathrm{Mn}$ & 0.2 & 1040 & 36 & 970 & 2570 & 82 & 2490 & 1071 & 53 & 1010 \\
\hline $\mathrm{S}$ & 20 & 844 & 31 & 784 & 246 & 21 & 200 & 244 & 70 & 90 \\
\hline $\mathrm{Nb}$ & 0.05 & 11.2 & 0.5 & 12 & 23.6 & 1.2 & 25 & 5.1 & 0.45 & 6.8 \\
\hline $\mathrm{Ta}$ & 0.05 & 0.67 & 0.04 & 0.75 & 5.16 & 0.36 & 5.7 & 0.31 & 0.03 & 0.44 \\
\hline $\mathrm{Te}$ & 0.1 & 0.16 & 0.02 & 0.14 & 0.44 & 0.05 & 0.38 & 0.087 & 0.004 & 0.08 \\
\hline $\mathrm{Bi}$ & 0.05 & 4.81 & 0.27 & 5 & 47.6 & 1.8 & 50 & 0.38 & 0.04 & 0.38 \\
\hline $\mathrm{Se}$ & 0.2 & 0.35 & 0.12 & 0.3 & 0.23 & 0.13 & 0.2 & 0.31 & 0.08 & 0.28 \\
\hline
\end{tabular}

$1.5 \mathrm{~h}$. The residue was rinsed with $5 \mathrm{ml} 25 \% \mathrm{CH} \mathrm{COOH}$, centrifuged, and supernatant was decanted into the test tube.

5. Stabile organic forms and sulfides - the residue from step 4 was leached with $750 \mathrm{mg}$ of $\mathrm{KClO}_{3}$ with an additional $5 \mathrm{ml}$ of $12 \mathrm{M} \mathrm{HCl}$. The sample was then vortexed and an additional $10 \mathrm{ml}$ of $\mathrm{HCl}$ was added. The sample was then left to sit for $30 \mathrm{~min}$ followed by the addition of $15 \mathrm{ml}$ of Milli-Q water and then centrifuged. The supernatant was later decanted into a new test-tube. The remaining residue was then leached with $4 \mathrm{M} \mathrm{HNO}_{3}$ and placed in a water bath at $90{ }^{\circ} \mathrm{C}$ for $20 \mathrm{~min}$. This was then centrifuged and supernatant decanted into a test tube. The residue was lastly rinsed a final time with $5 \mathrm{ml}$ of Milli-Q water, centrifuged, and subsequent supernatant extracted to a test tube. Element concentrations in all fractions were determined using ICP-SFMS.

\subsection{Sediment dating}

\subsubsection{Kallholmsfjärden core}

Dating of the sediment was done by using a combination of event markers: activity of radioactive ${ }^{137} \mathrm{Cs}$ (determined by gamma spectrometry at the Risø National Laboratory for

Table 2 Aluminium normalized major element ratios of Boliden's Iron Sand, regional till, upper continental crust (UCC), and the Kallholmsfjärden and Kullenberg cores

\begin{tabular}{|c|c|c|c|c|c|c|c|}
\hline & \multicolumn{7}{|c|}{ Element/Aluminium normalization } \\
\hline & $\begin{array}{l}\mathrm{Ca} / \\
\mathrm{Al}\end{array}$ & $\mathrm{Fe} / \mathrm{Al}$ & $\begin{array}{l}\mathrm{K} / \\
\mathrm{Al}\end{array}$ & $\begin{array}{l}\mathrm{Mg} / \\
\mathrm{Al}\end{array}$ & $\begin{array}{l}\mathrm{Na} / \\
\mathrm{Al}\end{array}$ & $\begin{array}{l}\mathrm{Si} / \\
\mathrm{Al}\end{array}$ & $\begin{array}{l}\mathrm{Ti} / \\
\mathrm{Al}\end{array}$ \\
\hline Iron Sand ${ }^{\mathrm{c}}$ & 1.46 & 14.23 & 0.41 & 0.46 & 0.45 & 4.76 & 0.04 \\
\hline Regional Till $^{\mathrm{a}}$ & 0.35 & 0.62 & 0.30 & 0.17 & 0.39 & 4.03 & 0.08 \\
\hline $\mathrm{UCC}^{\mathrm{b}}$ & 0.32 & 0.43 & 0.29 & 0.18 & 0.30 & - & 0.05 \\
\hline Kallholmsfjärden core ${ }^{\mathrm{c}}$ & 0.27 & 1.32 & 0.34 & 0.18 & 0.46 & 2.84 & 0.04 \\
\hline Kullenberg core $^{\mathrm{d}}$ & 0.23 & 0.83 & 0.37 & 0.23 & 0.34 & 3.90 & 0.06 \\
\hline
\end{tabular}

${ }^{\mathrm{a}}$ Land et al. (1999a)

${ }^{\mathrm{b}}$ Rudnick and Gao (2013)

${ }^{\mathrm{c}}$ This study

d Ingri et al. (2014) 


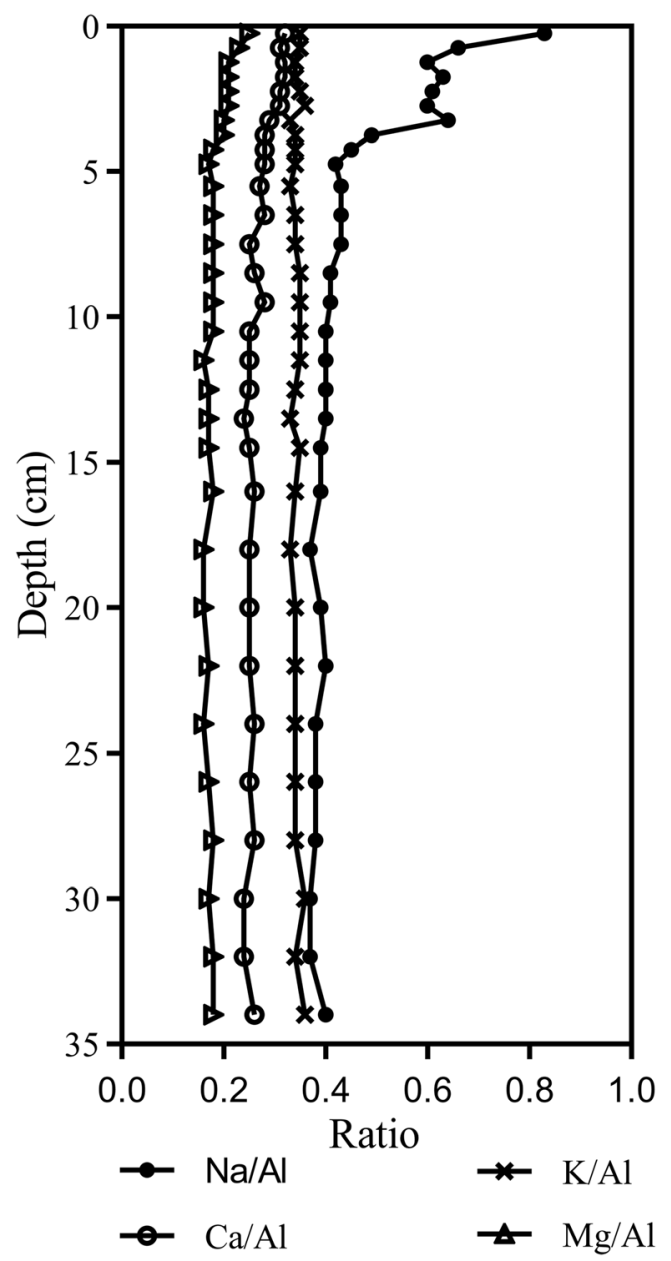

Fig. 2 Major element ratios in the Kallholmsfjärden sediment core

Sustainable Energy, Denmark) related to the Chernobyl nuclear power plant accident in 1986, and concentration markers based on known events in the industrial history of the area (see Section 4).

\subsubsection{Bothnian Bay cores}

For the 6-m-deep Kullenberg core, age determinations were done by the identification of key paleomagnetic signatures as described in Suteerasak et al. (2017). The direction of the natural remanent magnetization, as well as any reconstructed secular variations of the Earth's magnetic field, were compared with the FENNOSTACK master curve presented by Snowball and Sandgren (2002). This master curve identifies smoothed inclination and declination patterns of paleomagnetic data back to ca. 10,000 years BP. The dating is based on peaks of the master curve with corresponding maxima and minima of the relative declination and inclination identified by visual inspection (Suteerasak et al. 2017). The topmost part $(16 \mathrm{~cm})$ of the Gemini core was additionally dated using ${ }^{137} \mathrm{Cs}$ related to the Chernobyl nuclear power plant accident in 1986.

\subsection{Calculation of detrital and non-detrital sedimen- tary phases}

The detrital and non-detrital concentrations of $\mathrm{Fe}, \mathrm{Mn}$, Ta, and $\mathrm{Nb}$ in the Kallholmsfjärden core were calculated following the approach by Widerlund and Ingri (1996). Detrital Fe and $\mathrm{Mn}\left(\mathrm{Me}_{\mathrm{d}}\right.$, Eq. 1) were calculated assuming that all $\mathrm{Al}$ in the sediment $\left(\mathrm{Al}_{\mathrm{sed}}\right)$ originates from detrital material, with element composition $(\mathrm{Me} / \mathrm{Al})_{\mathrm{d}}$, of the sedimentary detrital phase being similar to that in local till within the Kalix River drainage area in Northern Sweden (Land et al. 1999a). Non-detrital Fe and Mn were calculated by subtracting the detrital fraction from the total concentration (Eq. 2). Non-detrital Fe is considered to be a mix of sulfide-bound Fe and HFOs. Sulfide-bound $\mathrm{Fe}$ is calculated from the $\mathrm{S}$ concentration in the sediment, assuming that all sulfur occurs as FeS, although part of the sulfur may also occur as pyrite $\left(\mathrm{FeS}_{2}\right)$ in anoxic Bothnian Bay sediments (Boman et al. 2008). The remaining non-detrital $\mathrm{Fe}$ is considered to consist of HFOs.

$\begin{aligned} \mathrm{Me}_{\mathrm{d}} & =\left(\frac{\mathrm{Me}}{\mathrm{Al}}\right)_{\mathrm{d}} \times \mathrm{Al}_{\mathrm{sed}} \\ \mathrm{Me}_{\mathrm{nd}} & =(\mathrm{Me})_{\text {tot }}-\mathrm{Me}_{\mathrm{d}}\end{aligned}$

Detrital and non-detrital $\mathrm{Ta}$ and $\mathrm{Nb}$ were also calculated using Eqs. (1) and (2), with detrital $\mathrm{Ta} / \mathrm{Al}$ and $\mathrm{Nb} / \mathrm{Al}$ ratios based on data for the UCC (Rudnick and Gao 2013). Considering the assumptions involved in this calculation, the distribution of $\mathrm{Fe}, \mathrm{Mn}, \mathrm{Ta}$, and $\mathrm{Nb}$ between the different phases should be seen as semi-quantitative. However, the presence of non-detrital $\mathrm{Fe}, \mathrm{Mn}, \mathrm{Ta}$, and $\mathrm{Nb}$ not bound to aluminosilicates is clearly demonstrated.

\subsection{Grain size analysis and XRD}

Particle size distributions in the samples were measured using a Cilas 1064 laser diffraction particle size analyzer with aqueous suspension. Six subsamples were taken from the Kullenberg core at depths $0.20-0.30 \mathrm{~m}, 0.50-0.75 \mathrm{~m}, 2.75$ $2.85 \mathrm{~m}, 3.65-3.75 \mathrm{~m}, 4.75-4.85 \mathrm{~m}$, and 5.65-5.75 m. Two samples were analyzed from the Kallholmsfjärden core between 11-13 cm depth and 23-27 cm depth.

The sediment mineralogical content was examined by ALS Scandinavia AB using a Philips X-ray diffractometer (XRD) with a CuK-alpha X-ray tube. The limit for the identification of phases was around $2 \%$ by weight. Samples were taken at depths 3-3.5 cm, 6-7 cm, 7-8 cm, and 33-35 cm. 
Fig. 3 Solid phase sediment profiles from the

Kallholmsfjärden sediment core. a Detrital-Fe, sulfide bound Fe, and non-detrital Fe considered to consist of HFOs (hydrous ferric oxides). b Detrital Mn and nondetrital Mn considered to consist of Mn oxyhydroxides

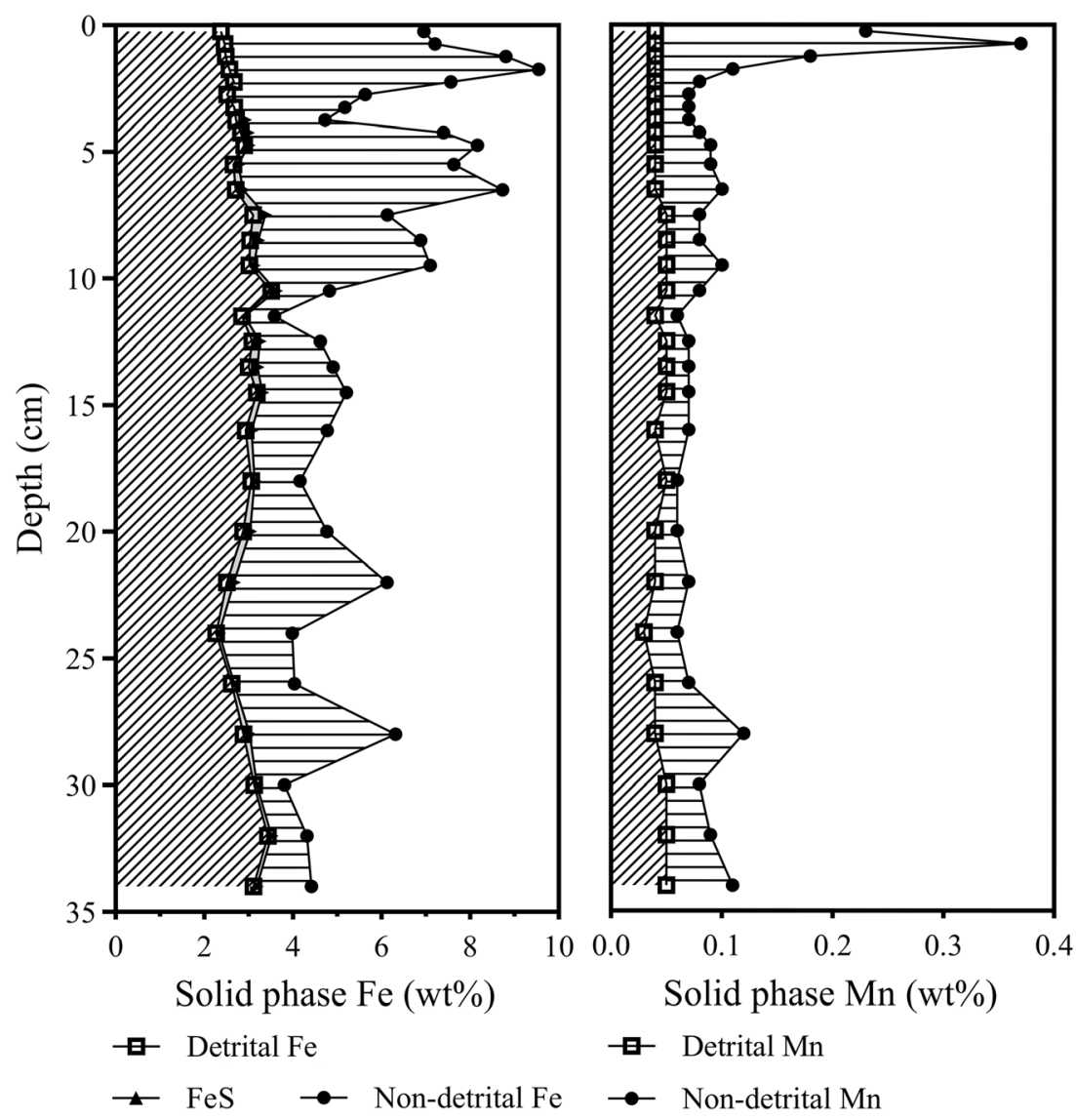

\section{Results and discussion}

\subsection{Sediment characteristics}

\subsubsection{Grain size analysis}

Sedimentological classes are described as "sand," "silt," and "clay," corresponding to size distributions of 2000-63 $\mu \mathrm{m}$, 63-2 $\mu \mathrm{m}$, and $<2 \mu \mathrm{m}$, respectively (Folk 1980). The grain size distributions from the laser granulometry measurements were shown to be consistent throughout both the Kallholmsfjärden core and the Kullenberg core from the open Bothnian Bay. The Kallholmsfjärden core has a rather constant composition of 11-15\% clay and 85-89\% silt content. A very similar content with approximately $12 \%$ clay and $88 \%$ silt was found for the Kullenberg core.

\subsubsection{Main element chemistry}

Aluminum was chosen as a normalizer for a group of elements associated with the detrital phase due to its high abundance in the Earth's crust, and its relatively little contribution from anthropogenic inputs (Windom et al. 1989). A strong $\left(r^{2}=0.89\right)$ positive correlation between $\mathrm{Al}$ and $\mathrm{Ti}$ concentrations further suggests natural aluminosilicates as the primary source of $\mathrm{Al}$ in the core samples with little influence from anthropogenic sources. The comparison of main element/Al ratios for the Iron Sand, regional till, UCC, and the sediment cores indicate that Iron Sand used to construct the Rönnskär industrial area exhibited little to no influence on the content of harbor bay sediments. This is indicated by the higher element/Al ratios for nearly all of the major elements in the Iron Sand (Table 2). The Kallholmsfjärden core shows greater similarities in the median element/Al ratios with both regional till and UCC values. Furthermore, the Kullenberg and the Kallholmsfjärden cores had similar $\mathrm{Ca} / \mathrm{Al}, \mathrm{K} / \mathrm{Al}$, and $\mathrm{Mg} / \mathrm{Al}$ ratios (Table 2), and all of the major element ratios are consistent throughout the Kallholmsfjärden core indicating no major change in the sediment composition (Fig. 2). The increase in $\mathrm{Na}$ in the first $5 \mathrm{~cm}$ of the core where the porosity is $\geq 95 \%$ is likely related to the precipitation of $\mathrm{NaCl}$ from pore water evaporation during drying of the sediment. These findings were further supported by XRD analysis where the mineral composition was shown to be consistent in all samples, with quartz, albite, microcline, and muscovite among the most abundant minerals. Though at low level, halite from evaporated pore water was also detected in the topmost sample. 
a

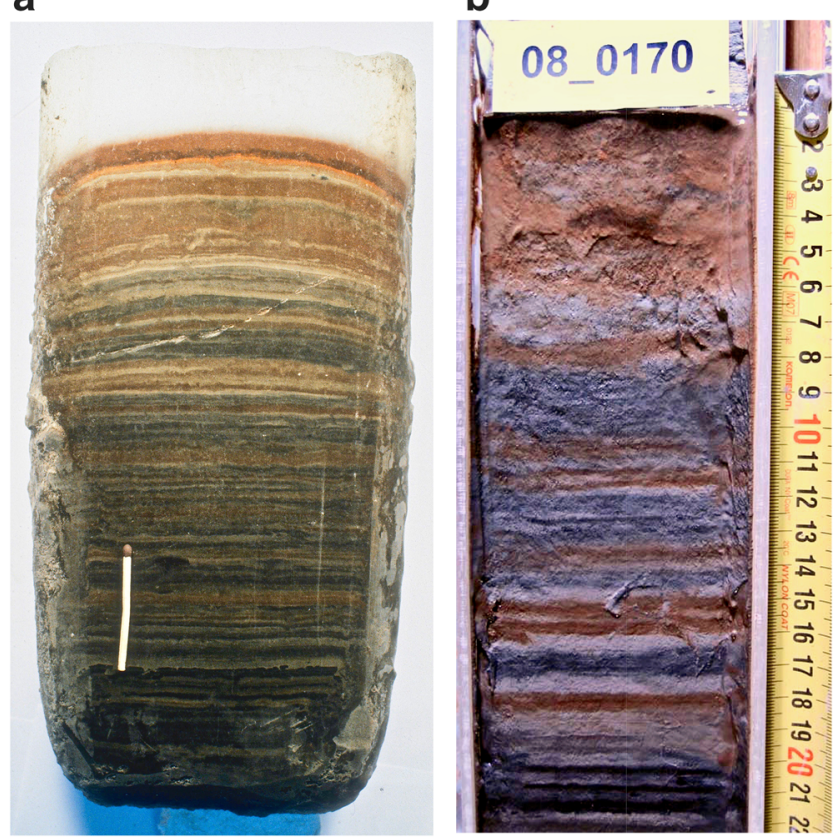

Fig. 4 a Varved sediment from the Kalix River estuary showing brown layers rich in HFOs buried in black, anoxic sediment. Black Mn oxides and reddish brown HFOs are precipitated in the oxic surface layer of the sediment (match is $50 \mathrm{~mm}$, Widerlund and Roos 1994). b Kullenberg core with laminated sediment from the open Bothnian Bay showing brown layers rich in HFOs buried in gray and black, anoxic sediment. The oxic surface layer of the sediment is indicated by the brown HFOs at the top of the core $(0-6 \mathrm{~cm})$

\subsubsection{Redox conditions}

The sharp peak of non-detrital Mn overlying the peak of nondetrital $\mathrm{Fe}$ (presumably consisting of $\mathrm{Mn}$ and $\mathrm{Fe}$ oxyhydroxides) indicates the presence of an approximately 2-cm-thick oxidized surface layer in the Kallholmsfjärden core (Fig. 3). Below this oxidized surface layer, non-detrital Fe contributes to $18-69 \%$ of total $\mathrm{Fe}$, and non-detrital $\mathrm{Mn}$ to 25-63\% of total Mn (Fig. 3). The presence of HFOs buried in suboxic and anoxic sediments is well known in the Bothnian Bay (Fig. 4, Ingri and Pontér 1986; Widerlund and Roos 1994; Widerlund and Ingri 1996). This strongly suggests that non-detrital Fe occurring in the suboxic and anoxic part of the sediment is composed of HFOs. Similarly, Mn oxyhydroxides buried in suboxic sediments and contributing to subsurface, non-detrital Mn (Fig. 3) have also been observed in the Bothnian Bay (Ingri and Pontér 1986).

\subsubsection{Sediment dating events in the Kallholmsfjärden core}

The sedimentation rate calculated for the core is based on known events using identifiable concentration peaks of $\mathrm{Bi}$, $\mathrm{Te}$, and Se related to different periods of activities at the Rönnskär smelter (Bergquist 2007), and ${ }^{137} \mathrm{Cs}$ related to the Chernobyl nuclear power plant accident in 1986.
Event 1-the start of the Rönnskär smelter The ore initially refined at the Rönnskär smelter was from the Boliden mine in the Skellefte Sulfide Ore District. This ore was rich in both Se and Te. Selenium and Bi were often associated, and Te mainly occurred as tellurobismuthite (Grip and Wirstam 1970). Concentrations of these two elements show a sharp increase from background levels at $29 \mathrm{~cm}$, caused by the Rönnskär smelter operations in 1930 (Fig. 5).

Event 2-the closing of the Boliden mine A marked decrease in $\mathrm{Se}, \mathrm{Te}$, and Bi concentrations at $19 \mathrm{~cm}$ depth (Fig. 5) is associated with the stop of operations at the Boliden Mine in 1967.

Event 3-Chernobyl accident of 1986 The artificial radionuclide ${ }^{137} \mathrm{Cs}$ has been introduced into lake and coastal sediments, both from global fallout following atmospheric nuclear bomb testing in the 1950s and 1960s as well as regionally from the Chernobyl accident in 1986. Around 5\% of the ${ }^{137} \mathrm{Cs}$ released from the Chernobyl power plant was deposited in Sweden; the highest amount of fallout being along the eastern coast of Sweden (Alinaghizadeh et al. 2016). The spike in ${ }^{137} \mathrm{Cs}$ activity was used as an event marker for the Chernobyl accident in 1986 (Fig. 5).

Thus, three events over 56 years have been identified, which all give a consistent average sedimentation rate of $0.34 \mathrm{~cm}$ year $^{-1}$. The dated core profile is plotted in Fig. 5 .

\subsection{Niobium and Tantalum in the Bothnian Bay cores}

The 6-m-deep Kullenberg core dating back 7000 years BP provides one of the longest records for $\mathrm{Nb}$ and $\mathrm{Ta}$ background concentration in the Baltic Sea. The core profile shows only minor concentration variations for $\mathrm{Nb}$ and $\mathrm{Ta}$, with an average $\mathrm{Nb}$ concentration of $12 \pm 0.7 \mathrm{ppm}$, and Ta concentrations of $0.91 \pm 0.08 \mathrm{ppm}(n=93)$ (Fig. 6). Both Ta and $\mathrm{Nb}$ coincides with the UCC values of $12 \mathrm{ppm}$ for $\mathrm{Nb}$ and $0.92 \mathrm{ppm}$ for $\mathrm{Ta}$ (Rudnick and Gao 2013). The $\mathrm{Nb} / \mathrm{Ta}$ mass ratio averages at $13.16 \pm 0.61$, which is slightly higher than the UCC ratio of 12. There also seems to be a slight increasing trend in the ratio throughout the Kullenberg core though reasons for this increase are not known. However, it is unlikely that this is related to an anthropogenic influence as this increase expands the length of the core past 7000 years BP.

The top $16 \mathrm{~cm}$ of the Gemini core dated 1945-2005 displayed no variations in the $\mathrm{Nb}$ and $\mathrm{Ta}$ concentrations and the $\mathrm{Nb}$ /Ta ratio (Fig. 6). Niobium and Ta concentrations averaged at around $10.5 \pm 0.4 \mathrm{ppm}$ and $0.87 \pm 0.03 \mathrm{ppm}$, respectively, with average $\mathrm{Nb} / \mathrm{Ta}$ ratio of $12 \pm 0.3(n=16)$. The close correlation between the Kullenberg and Gemini core concentrations as well as fairly constant $\mathrm{Ta}$ and $\mathrm{Nb}$ concentrations close to UCC values indicates very little to no anthropogenic load of these two elements in this part of the Bothnian Bay. 
Fig. 5 Event dating in the Kallholmsfjärden sediment core using ${ }^{137} \mathrm{Cs}, \mathrm{Te}, \mathrm{Bi}$, and $\mathrm{Se}$ as event markers. The three dating events all give a consistent average sedimentation rate of $0.34 \mathrm{~cm}_{\text {year }}{ }^{-1}$

Fig. 6 Dated Kullenberg core profile of $\mathrm{Ta}$ and $\mathrm{Nb}$

concentrations and the $\mathrm{Nb} / \mathrm{Ta}$ ratio in the open Bothnian Bay. a, b Kullenberg core. c Gemini core showing concentrations in the top $16 \mathrm{~cm}$ of the sediment
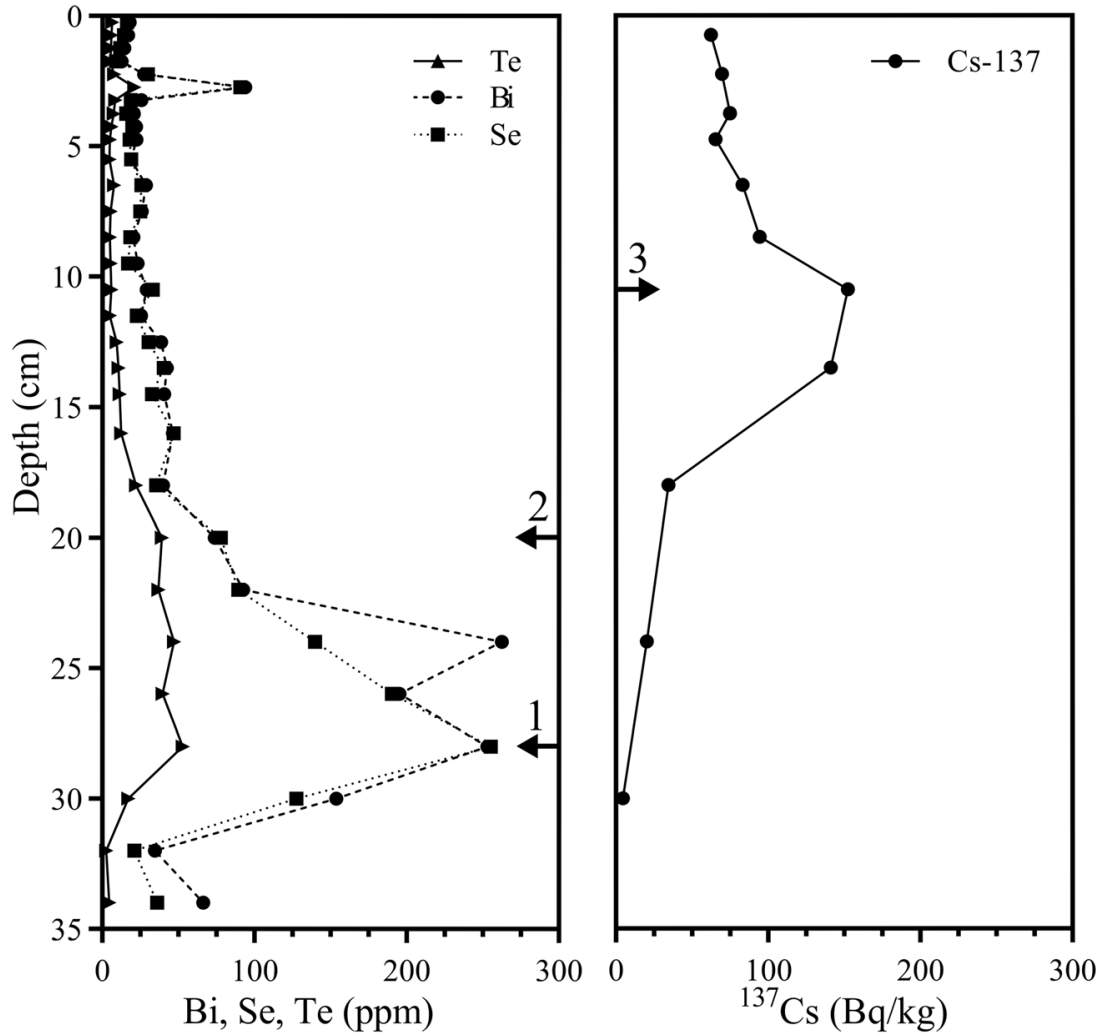

1: Start of the Rönnskär Smelter (1930)

2: Closing of the Boliden Mine (1967)

3: Chernobyl Accident of 1986
$\mathrm{Ta}(\mathrm{ppm})$

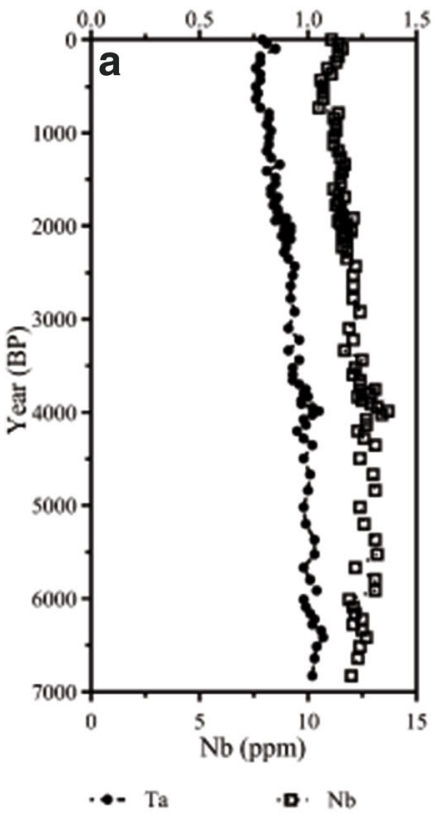

$\mathrm{Ta}(\mathrm{ppm})$
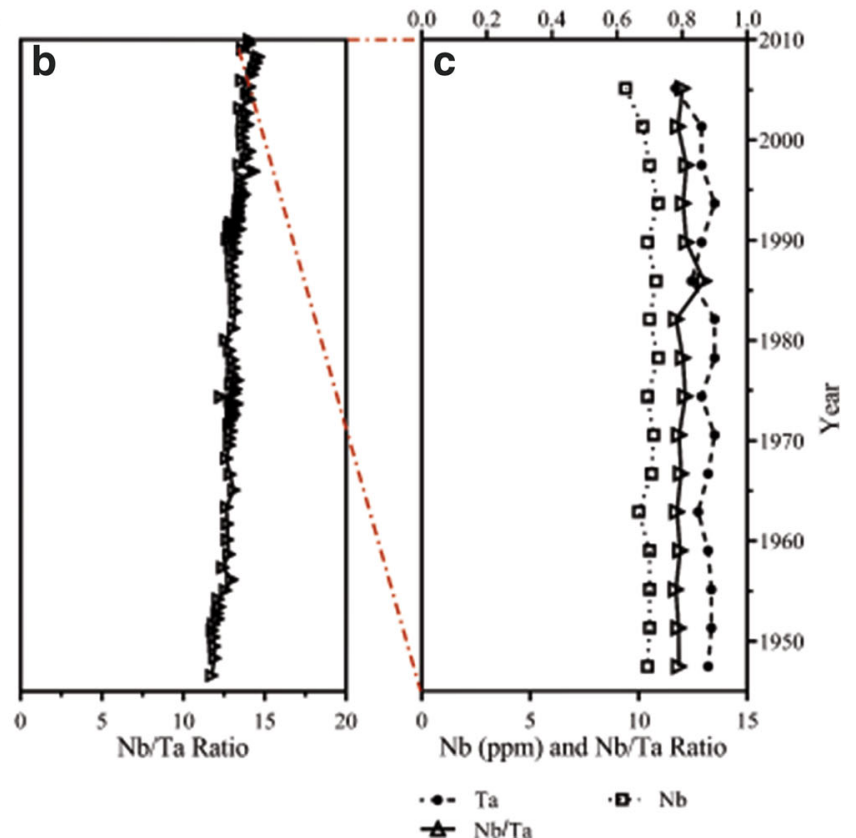
Table 3 Published $\mathrm{Nb}$ and Ta concentrations at other marine/terrestrial sites

\begin{tabular}{llllll}
\hline Author & Year & Location & Sediment type & Nb (ppm) & Ta (ppm) \\
\hline Plank and Languimir & 1998 & World & UCC & $13.7 \pm 0.9$ & $0.96 \pm 0.12$ \\
Gao et al. & 1998 & World & UCC & 12 & 0.74 \\
Barth et al. & 2000 & World & Loess & $13 \pm 2.6$ & $1.02 \pm 0.26$ \\
& & & Post-Archean Australian Shale (PAAS) & $15.6 \pm 4.4$ & $1.28 \pm 0.30$ \\
& & & UCC & $11.5 \pm 2.6$ & $0.92 \pm 0.12$ \\
Åström et al. & 2008 & Europe, Baltic Sea & Brackish water sediments & $1.33-4.20$ & - \\
& & & Lacustrine & $0.25-0.53$ & -- \\
Sohlenius and Hedenström & 2008 & Laxemar-Simpevarp, Sweden & Glacial till & $9.7 \pm 1.92$ & $0.86 \pm 0.19$ \\
Andersson & 2014 & Västerbotten Sweden & Glacial till & - & 2.9 \\
Bayon et al. & 2015 & World & Riverine & 16 & 1.1 \\
Fang et al. & 2018 & Xiangjiang River, China & Riverine & 17.77 & 2.17 \\
& & Yuanjiang River, China & Riverine & 16.51 & 1.31 \\
Ray et al. & 2020 & Bay of Bengal, Lothian Island India & Riverine & $38.3 \pm 3.6$ & $2.85 \pm 0.76$ \\
& & Bay of Bengal, Jharkahli Island India & Riverine & $34.2 \pm 3.9$ & $3.39 \pm 0.34$ \\
& & & &
\end{tabular}

Fig. 7 Solid phase sediment profiles from the

Kallholmsfjärden sediment core. a Detrital Ta and non-detrital Ta. Non-detrital Ta occurring after 1960 is interpreted to be of anthropogenic origin (75-90\% of total Ta after 1995). b Detrital Nb and non-detrital Nb. Detrital Nb forms $84-100 \%$ of total $\mathrm{Nb}$ throughout the core, reflecting the lithophile nature of $\mathrm{Nb}$

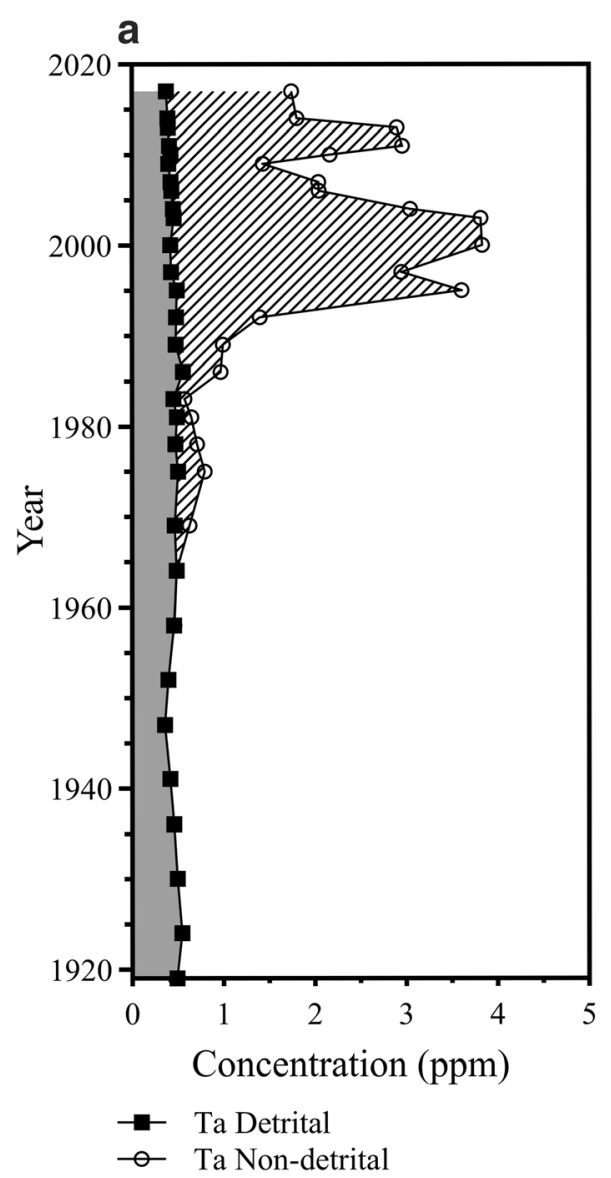

b

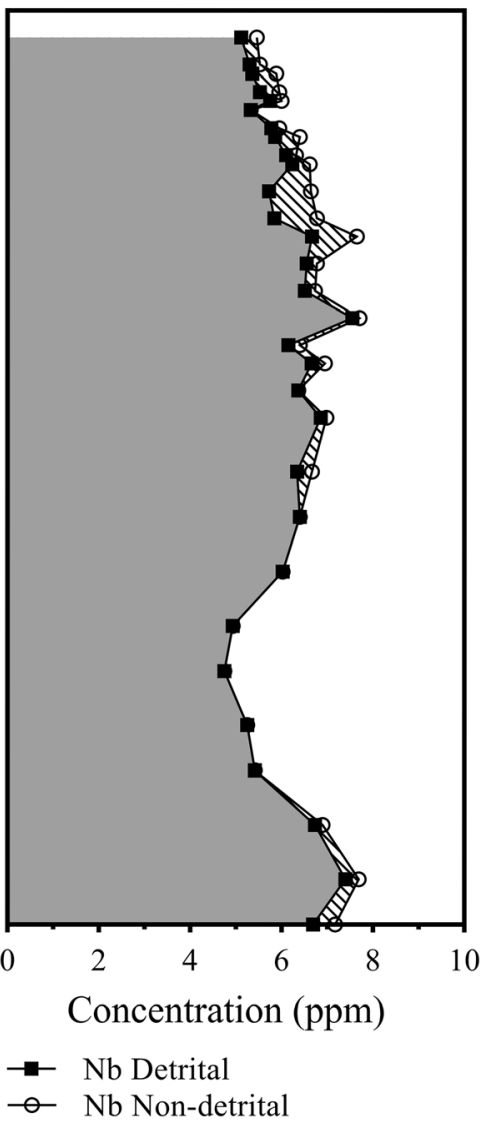


Fig. 8 Proportion of $\mathrm{Nb}$ extracted in each leach step from the different depths within the Kallholmsfjärden core. Each leaching step accounts for the following fractions: (1) adsorbed and exchangeable metals, (2) labile organic forms, (3) amorphous $\mathrm{Fe} / \mathrm{Mn}$ oxides, (4) crystalline Fe oxides, (5) stable organic forms and sulfides

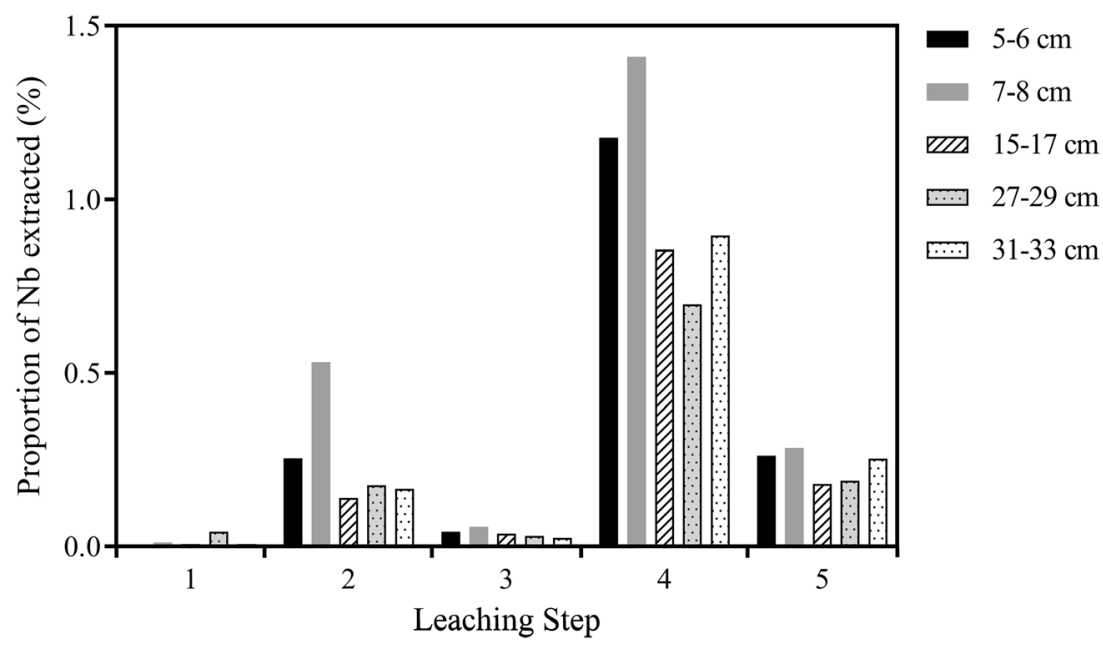

\subsection{Niobium and Tantalum in the Kallholmsfjärden core}

\subsubsection{Niobium}

The $\mathrm{Nb}$ concentration in the Kallholmsfjärden core profile displays moderate variation with depth. The average core concentration for $\mathrm{Nb}$ is $6.33 \pm 0.78 \mathrm{ppm}$, which is lower than both the Kullenberg core from the open Bothnian Bay and UCC values (Table 3). Niobium in glacial till in Västerbotten county (county in which the Rönnskär smelter is located) often are much lower than what is generally seen on a global scale. Average concentrations measured by the geological survey of Sweden are around $2.9 \mathrm{ppm}$ with the highest
Fig. 9 Dated profile showing the relationship between Ta and nondetrital Fe (HFOs) and detrital Fe in the Kallholmsfjärden core. From 1965 up to the present, $r^{2}$ between Ta and HFOs is 0.50

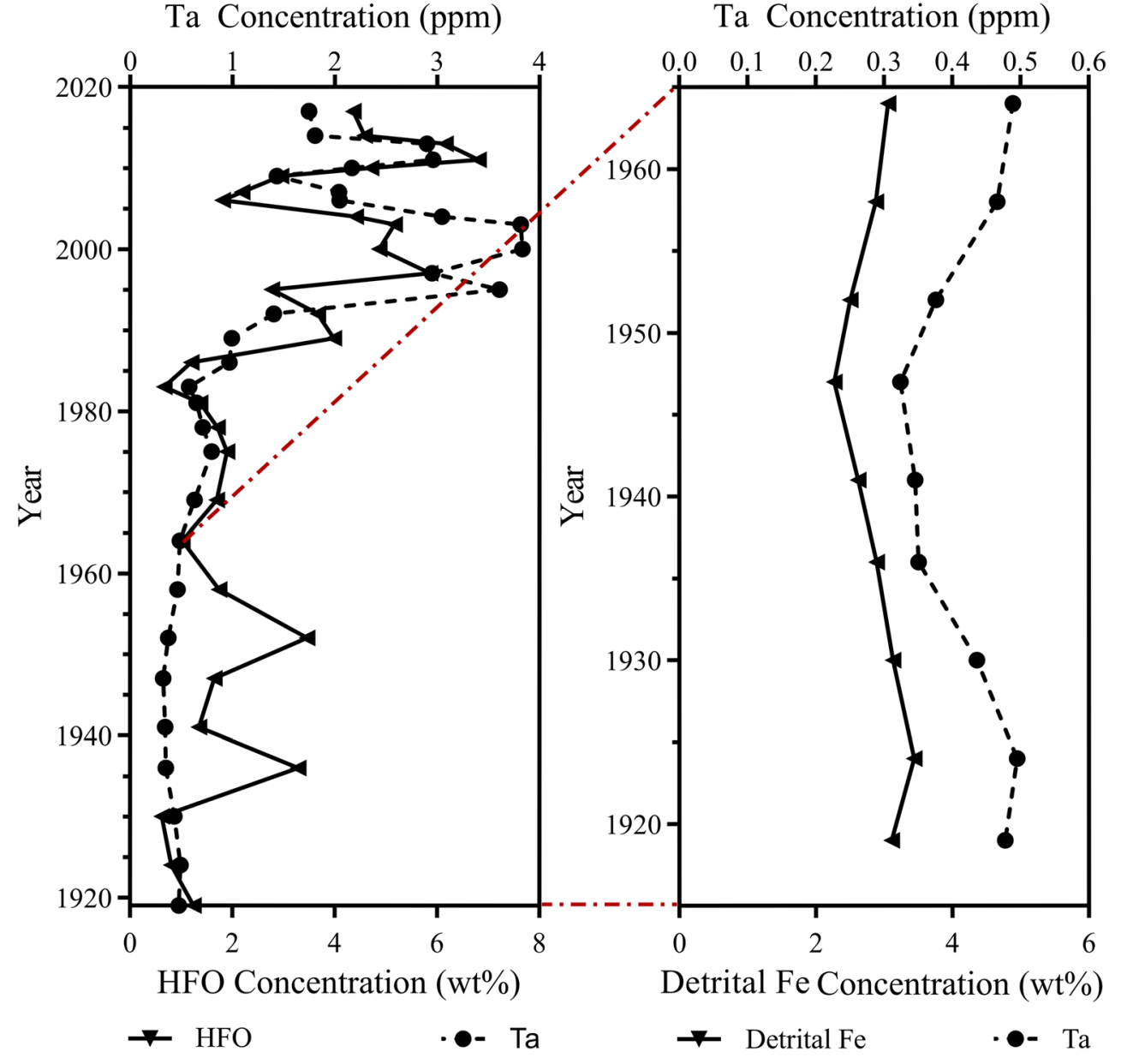


Table 4 Extracted proportions of $\mathrm{Ta}$ and $\mathrm{Nb}$ from the five sequential leaching steps at different depth within the Kallholmsfjärden core. Each leaching step accounts for the following fractions: (1) adsorbed and exchangeable metals, (2) labile organic forms, (3) amorphous $\mathrm{Fe} / \mathrm{Mn}$ oxides, (4) crystalline Fe oxides, and (5) stable organic forms and sulfides

\begin{tabular}{|c|c|c|c|c|c|c|c|c|c|c|}
\hline \multirow[t]{3}{*}{ Depth $(\mathrm{cm})$} & \multicolumn{10}{|c|}{ Proportion removed in each leaching step (\%) } \\
\hline & \multicolumn{2}{|l|}{1} & \multicolumn{2}{|l|}{2} & \multicolumn{2}{|l|}{3} & \multicolumn{2}{|l|}{4} & \multicolumn{2}{|l|}{5} \\
\hline & $\mathrm{Ta}$ & $\mathrm{Nb}$ & $\mathrm{Ta}$ & $\mathrm{Nb}$ & $\mathrm{Ta}$ & $\mathrm{Nb}$ & $\mathrm{Ta}$ & $\mathrm{Nb}$ & $\mathrm{Ta}$ & $\mathrm{Nb}$ \\
\hline $5-6$ & 0.0 & 12.5 & 69.0 & 20.5 & 72.6 & 20.0 & 0.0 & 23.3 & 100.0 & 22.1 \\
\hline $7-8$ & 60.9 & 12.5 & 31.0 & 40.9 & 22.6 & 30.0 & 0.0 & 28.1 & 0.0 & 24.6 \\
\hline $15-17$ & 34.8 & 12.5 & 0.0 & 11.4 & 2.8 & 20.0 & 0.0 & 17.0 & 0.0 & 15.6 \\
\hline $27-29$ & 0.0 & 50.0 & 0.0 & 14.4 & 0.0 & 15.0 & 0.0 & 13.8 & 0.0 & 16.4 \\
\hline $31-33$ & 4.3 & 12.5 & 0.0 & 12.9 & 1.9 & 15.0 & 100.0 & 17.8 & 0.0 & 21.3 \\
\hline
\end{tabular}

99 percentile reaching global averages at $11 \mathrm{ppm}$ (Andersson 2014) (Table 3). The values in the Kallholmsfjärden core are shown to be similar to $\mathrm{Nb}$ concentrations in glacial till presented in other studies based in Sweden and around the Baltic Sea (Åström et al. 2008; Sohlenius and Hedenström 2008). However, these values are considered to be low compared to global averages (Table 3).

Concentrations of $\mathrm{Nb}$ and $\mathrm{Al}$ closely $\left(r^{2}=0.75\right)$ correlate, indicating a detrital, natural origin. Throughout the core, the share of detrital $\mathrm{Nb}$ corresponds to $86-100 \%$ of total $\mathrm{Nb}$ (Fig. 7), a clear reflection of the lithophile nature of $\mathrm{Nb}$. However, from about 1960, non-detrital $\mathrm{Nb}$ makes up a minor fraction (0-14\%) of total $\mathrm{Nb}$ (Fig. 7). The opening of the Rönnskär smelter or the start of scrap metal and electronic waste processing appear to have had no major effect on $\mathrm{Nb}$ concentrations. Therefore, the $\mathrm{Nb}$ present in the Kallholmsfjärden core is dominated by $\mathrm{Nb}$ from natural weathering processes rather than from anthropogenic source(s). The lower concentrations of $\mathrm{Nb}$ compared to other areas of the Bothnian Bay are likely due to a natural variance from the catchment area.

Sequential leaching showed that $\mathrm{Nb}$ was primarily present in the labile organic and crystalline Fe oxide fractions as well as the stable organic and sulfide fractions (Fig. 8). There was no observed inclination toward any specific associated fraction with respect to depth.

\subsubsection{Tantalum}

In contrast to $\mathrm{Nb}$, the Kallholmsfjärden profile shows a large variation in Ta concentrations throughout the core (Figs. 7 and 9). Prior to the mid-1960s, Ta concentrations were relatively stable, with an average value of $0.42 \mathrm{ppm}$. This is lower than the concentrations in the open Bothnian Bay (Kullenberg core) as well as UCC values $(0.91 \pm 0.08 \mathrm{ppm})$. Unfortunately, no values were given by the Swedish Geological Survey for Västerbotten county. However, glacial till values presented by Sohlenius and Hedenström 2008 measured concentrations around $0.86 \pm 0.19 \mathrm{ppm}$, similar to both the Bothnian Bay and UCC (Table 3).

From 1965 to 1983, Ta concentrations increased to an average of $0.67 \mathrm{ppm}$, corresponding in time with the beginning of scrap metal processing at the Rönnskär smelter in the 1960s (Fig. 8). The primary use of Ta during this time was industrial applications for its mechanical properties and corrosion resistance. It was therefore primarily present in cutting tools, abrasion-resistant surfaces, agitators, heat exchangers, pipes, valves, nozzles, spinnerets for rayon spinning,
Fig. 10 Proportion of Ta extracted in each leaching step from the different depths within the Kallholmsfjärden core. Each leaching step accounts for the following fractions: (1) adsorbed and exchangeable metals, (2) labile organic forms, (3) amorphous $\mathrm{Fe} / \mathrm{Mn}$ oxides, (4) crystalline Fe oxides, (5) stable organic forms and sulfides

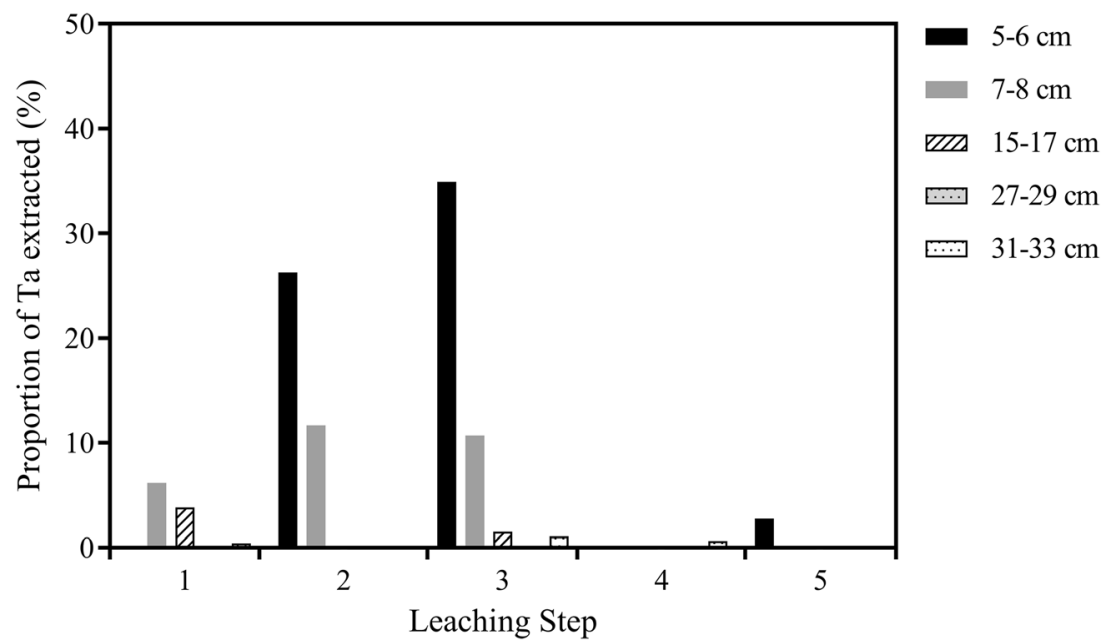


$\mathrm{Ta}, \mathrm{Nb}$ Concentration (ppm)

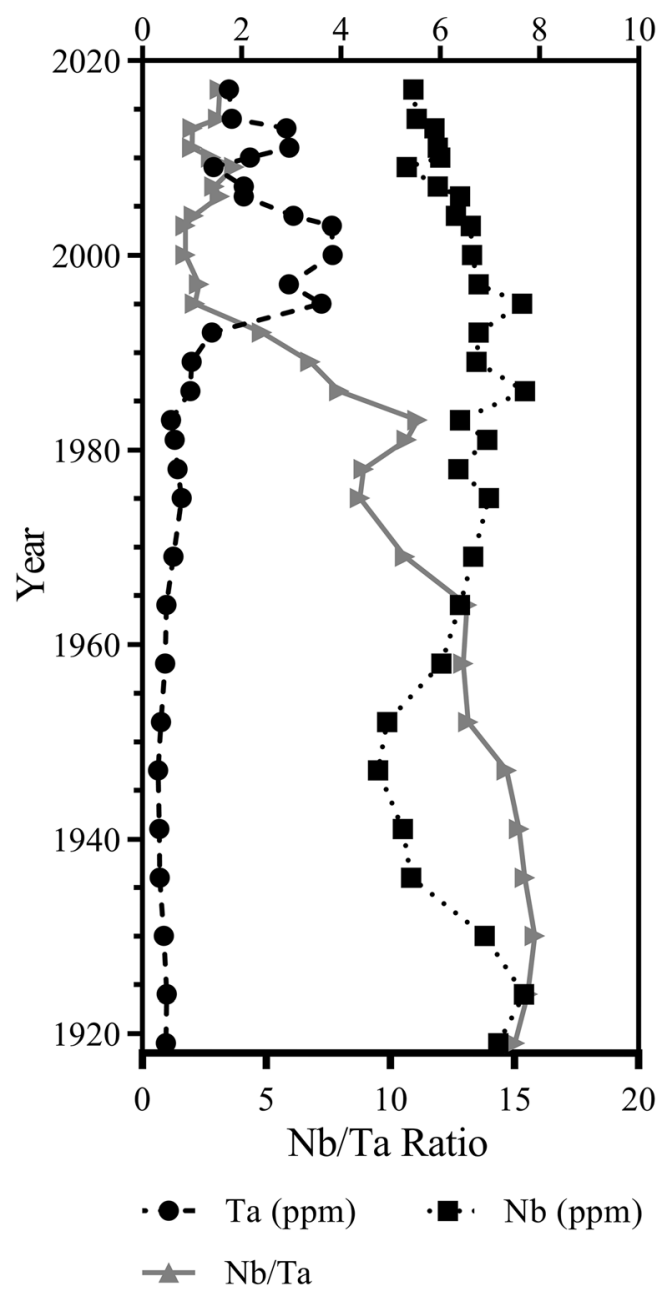

Fig. 11 Dated core profile of $\mathrm{Nb}$ and $\mathrm{Ta}$ concentrations and the $\mathrm{Nb} / \mathrm{Ta}$ mass ratio in the Kallholmsfjärden core

and thermometer wells (Espinoza 2012). It could also be possible that the Ta increase seen during this time was due to the processing of a new ore type. However, $\mathrm{Nb}$ would then also show an increase in concentration, which is not seen in this core (Fig. 7). Following 1983, there is a sharp increase in non-detrital Ta concentrations coinciding with the beginning of electronic scrap processing at Rönnskär (Figs. 7 and 9). Electronic components became the dominant use of Ta between the 1960s and 1970s, which continues today, with $60 \%$ of Ta being used for Ta capacitors (Espinoza 2012). The non-detrital Ta concentration in the core peaks between 1995 and 2005, where maximum Ta levels of approximately $3.8 \mathrm{ppm}$ are approximately ten times the pre-industrial values at the bottom of the core. From 1995 to 2017, non-detrital Ta accounts for 75$90 \%$ of total $\mathrm{Ta}$, while it is generally $<5 \%$ before 1960 (Fig. 7). A second peak is also visible between 2010 and 2015, which could coincide with the opening of the dedicated electronic waste processing E-kaldo furnace at Rönnskär.

Anthropogenic Ta seems to be associated with HFOs in the sediment, which is reflected in the similarity of concentration trends from 1965 upwards (Fig. 9). This association does not seem to be the case with natural Ta (before 1965), which appears to be more closely related to detrital components similar to what was shown with $\mathrm{Nb}$. A moderately strong correlation of $r^{2}=0.50$ exists between HFOs and the total Ta concentration following 1965 .

Ta concentrations obtained from the sequential extraction were in agreement with the calculated non-detrital Ta concentrations (Fig. 7), where $92.5 \%$ of leachable Ta was in the upper portion of the core (Table 4 and Fig. 10). At depths 5$6 \mathrm{~cm}$ (dated to 2001), Ta was primarily in the labile organic (26.3\%), and amorphous $\mathrm{Fe} / \mathrm{Mn}$ oxide fractions $(35.0 \%)$ as well as in the stabile organic forms and sulfide fractions, but to a much lesser extent (2.8\%) (Fig. 10). Congruent results at $7-8 \mathrm{~cm}$ depth (dated to 1995), exhibited a partitioning of Ta primarily in the exchangeable (6.2\%), labile organic (11.7\%), and the amorphous $\mathrm{Fe} / \mathrm{Mn}$ fractions (10.7\%). At $15-17 \mathrm{~cm}$ depth (dated to 1971), inorganic Ta was primarily in the exchangeable (3.8\%) and amorphous $\mathrm{Fe} / \mathrm{Mn}$ fractions (1.5\%). At depths 27-29 cm ( 1936), no leachable Ta was present and is assumed to be primarily in the detrital phase. In the deepest part of the core at 31--33 cm ( 1924), very little leachable Ta was present though slight concentrations were extracted in the exchangeable $(0.4 \%)$, amorphous $\mathrm{Fe} / \mathrm{Mn}$ oxides $(1.1 \%)$, and crystalline Fe oxides $(0.7 \%)$.

\subsection{3 $\mathrm{Nb} / \mathrm{Ta}$ ratios}

$\mathrm{The} \mathrm{Nb} / \mathrm{Ta}$ mass ratio profile in the Kallholmsfjärden core is opposite to the Ta concentration profile (Fig. 11). Prior to 1965 , the $\mathrm{Nb} / \mathrm{Ta}$ ratio is relatively constant, with an average value of $14.5 \pm 0.55$. This is slightly higher than what was seen in the open Bothnian Bay (13.16 in Kullenberg core), as well as the UCC value (12). This variation in the background ratios of the different locations is likely a reflection of different catchment geologies. Between 1965 and 1985, a general decline in the $\mathrm{Nb} / \mathrm{Ta}$ ratio can be seen, followed by a sharper decrease during 1985-1995. This further suggests that a new anthropogenic source of Ta is being introduced. The dating of these events coincides with the scrap metal and electronic processing activities at the Rönnskär smelter.

\subsubsection{Implications for Ta mobility and toxicity}

The association of Ta with HFOs and organic matter may affect the transport of Ta in aqueous systems. Suspended HFO particles have been shown to have high aggregation but low settling during transport through the coastal zone out into the open Bothnian Bay (Gustafsson et al. 2000). This is confirmed by the high Fe 
concentrations observed in the oxidized surface layer of the open Bothnian Bay sediments (Boström et al. 1983), where the $\mathrm{Fe} / \mathrm{Al}$ mass ratio (1.3) is twice that in local glacial till (0.62). These HFOs could in turn act as a carrier for Ta out into the Bothnian Bay, although in this study, no rise in the concentration of Ta was observed in the open Bothnian Bay (Fig. 6).

It is well known that the early diagenetic behavior of trace metals may be controlled by the redox cycling of $\mathrm{Fe}$ and $\mathrm{Mn}$ in surface sediments (Cornwell 1986; Widerlund and Ingri 1996). The apparent association of Ta to amorphous Fe/Mn oxides, with the $\mathrm{Fe}$ oxides presumably occurring in buried HFO layers (Figs. 4 and 9), could thus have important effects on the distribution and accumulation of Ta in the Bothnian Bay sediments. In the suboxic and anoxic zones, the reduction of buried HFO layers could compromise adsorption sites and thereby re-mobilize the Ta in the sediment column. This Ta could then be re-adsorbed by secondary HFOs precipitated in the oxic surface sediment. The redox cycling of Fe could therefore blur the timing of the actual increase or decrease in Ta concentrations seen in the core, and also affect the Ta concentrations where HFOs are present. In standard toxicological information sources, there is very little information on exposure limits for Ta (OSHA 2014). However, the samples in this study were taken in Bothnian Bay sediments and are likely to have very little direct exposure to the population of Skellefteå. Although it is possible that there may be some exposure from ingestion of fish from Kallholmsfjärden, this would need further investigation.

\section{Conclusion}

Niobium concentrations in the Kallholmsfjärden sediment core show no notable change compared to the pre-industrial background. Temporal trends of $\mathrm{Nb}$ concentrations closely follow detrital $\mathrm{Al}$, indicating predominantly a natural origin of the element. Average $\mathrm{Nb}$ concentrations for the Kallholmsfjärden core were slightly lower than average concentrations for the UCC while $\mathrm{Nb}$ concentrations for the Kullenberg core from the open Bothnian Bay where more similar. Leachable $\mathrm{Nb}$ was predominantly in the labile organic fractions, the crystalline $\mathrm{Fe}$ oxides, and the stabile organics and sulfides fraction. Leachable fractions of $\mathrm{Nb}$ did not show any noticeable change with depth in the sediment.

Concentrations of $\mathrm{Ta}$ in the Kallholmsfjärden core increase from background following the beginning of electronic waste processing at the Rönnskär smelter. Similarly to $\mathrm{Nb}$, Ta concentrations follow detrital $\mathrm{Al}$ trends prior to the start of electronic processing, while after this time Ta concentrations increase up to ten-fold the background levels. At this time, non-detrital Ta starts to dominate in the sediment. Sequential leaching showed that the majority of non-detrital $\mathrm{Ta}(92 \%)$ was in the upper portion of the sediment (between 5 and $15 \mathrm{~cm}$ ). Above $15 \mathrm{~cm}$, Ta was extracted from labile organic fractions and amorphous $\mathrm{Fe} / \mathrm{Mn}$ oxide fractions. Below $15 \mathrm{~cm}$, Ta was primarily extracted from adsorbed and exchangeable fractions and crystalline $\mathrm{Fe}$ oxides. This association between Ta and HFOs may have important implications for the assessment of mobility of Ta in aquatic systems. This may be particularly true if Ta of anthropogenic origin is increasingly bound to HFOs as suggested by our data from the Kallholmsfjärden core, where non-detrital Ta accounts for 75 $90 \%$ of total Ta from 1995 up to the present. However, the average Ta concentrations in the cores from the open Bothnian Bay remained near UCC values (top of Gemini core) suggesting little to no influence of anthropogenic Ta contamination.

$\mathrm{The} \mathrm{Nb} / \mathrm{Ta}$ ratio changed significantly following the beginning of electronic scrap processing at the Rönnskär smelter. The change in the ratio between these two elements is due to an anthropogenic influence, suggesting that the $\mathrm{Nb} / \mathrm{Ta}$ ratio can be used in future studies for tracing Ta of anthropogenic origin.

Acknowledgments This project was funded by The Swedish Agency for Economic and Regional Growth, and Region Norrbotten. We would like to thank Boliden Mineral AB for their support and assistance in the project. We are also appreciative to the Geological Survey of Sweden for assistance with the core sampling in the Bothnian Bay. For the use of their laboratories and the supplies provided for sampling and analysis, $A L S$ Scandinavia is gratefully acknowledged.

Funding Open Access funding provided by Lulea University of Technology. This project was funded by The Swedish Agency for Economic and Regional Growth, and Region Norrbotten.

Data availability Not applicable.

\section{Compliance with ethical standards}

Conflict of interest The authors declare that they have no conflict of interest.

Code availability Not applicable.

Open Access This article is licensed under a Creative Commons Attribution 4.0 International License, which permits use, sharing, adaptation, distribution and reproduction in any medium or format, as long as you give appropriate credit to the original author(s) and the source, provide a link to the Creative Commons licence, and indicate if changes were made. The images or other third party material in this article are included in the article's Creative Commons licence, unless indicated otherwise in a credit line to the material. If material is not included in the article's Creative Commons licence and your intended use is not permitted by statutory regulation or exceeds the permitted use, you will need to obtain permission directly from the copyright holder. To view a copy of this licence, visit http://creativecommons.org/licenses/by/4.0/.

\section{References}

Alinaghizadeh H, Wålinder R, Vingård E, Tondel M (2016) Total cancer incidence in relation to $137 \mathrm{Cs}$ fallout in the most contaminated counties in Sweden after the Chernobyl nuclear power plant 
accident: a register-based study. BMJ Open 6:1-8. https://doi.org/ 10.1136/bmjopen-2016-011924

Andersson M (2014) Geokemisk Atlas Över Sverige - Geochemical Atlas of Sweden. Sveriges Geologiska Undersökning

Åström ME, Peltola P, Virtasalo JJ, Kotilainen AT, Salminen R (2008) Niobium in boreal stream waters and brackish-water sediments. Geochemistry Explor Environ Anal 8:139-148. https://doi.org/10. 1144/1467-7873/07-155

Barth MG, McDonough WF, Rudnick RL (2000) Tracking the budget of $\mathrm{Nb}$ and Ta in the continental crust. Chem Geol 165:197-213. https:// doi.org/10.1016/S0009-2541(99)00173-4

Bayon G, Toucanne S, Skonieczny C, André L, Bermell S, Cheron S, Dennielou B, Etoubleau J, Freslon N, Gauchery T, Germain Y, Jorry SJ, Ménot G, Monin L, Ponzevera E, Rouget ML, Tachikawa K, Barrat JA (2015) Rare earth elements and neodymium isotopes in world river sediments revisited. Geochim Cosmochim Acta 170:1738. https://doi.org/10.1016/j.gca.2015.08.001

Bergquist A-K (2007) Guld och Gröna Skogar ? Miljöanpassningen av Rönnskärsverken 1960-2000. Umeå universitet

Blomqvist S, Abrahamsson B (1985) An improved Kajak-type gravity core sampler for soft bottom sediments. Swiss J Hydrol 47:1-4

Boman A, Åström M, Fröjdö S (2008) Sulfur dynamics in boreal acid sulfate soils rich in metastable iron sulfide-The role of artificial drainage. Chem Geol 255:68-77. https://doi.org/10.1016/j. chemgeo.2008.06.006

Boström K, Burman J-O, Ingri J (1983) A geochemical massbalance for the Baltic. Ecol Bull 35:39-58

Brydsten L (1993) Characterization of transport bottoms in the Gulf of Bothnia - a model approach. Aqua Fenn 23:153-164 03567133

Cartier C, Hammouda T, Boyet M, Bouhifd MA, Devidal JL (2014) Redox control of the fractionation of niobium and tantalum during planetary accretion and core formation. Nat Geosci 7:573-576. https://doi.org/10.1038/ngeo2195

Cerny P, Ercit TS (1989) Mineralogy of Niobium and Tantalum: crystal chemical relationships, paragenetic aspects and their economic implications. Mineral Ta Nb 54. https://doi.org/10.1007/978-3-64287262-4

Chandrajith R, Dissanayake CB, Tobschall HJ (2001) Enrichment of high field strength elements in stream sediments of a granulite terrain in Sri Lanka - evidence for mineralized belt. Chem Geol 175:259271. https://doi.org/10.1016/S0009-2541(00)00293-X

Ciaravino C, Medeiros FFP, De Souza CP, Roubin M (2002) Elaboration of mixed tantalum and niobium carbides from tantalite mineral $(\mathrm{Fe}$, Mn)(Ta1-xNbx)2O6. J Mater Sci 37:2117-2123. https://doi.org/10. 1023/A:1015202205033

Cornwell JC (1986) Diagenetic trace-metal profiles in Arctic lake sediments. Environ Sci Technol 20:299-302. https://doi.org/10.1021/ es $00145 \mathrm{a} 012$

Emsley J (2001) Nature's Building Blocks: an A-Z guide to the elements. Oxford University press, New York

Espinoza LAT (2012) Case study : Tantalum in the world economy : history, uses and demand. POLINARES working paper no. 28. https://polinares.eu/docs/d2-1/polinares_wp2_chapter16.pdf. Accessed 1 Nov 2019

Fairbrother F (1967) The chemistry of Niobium and Tantalum, Elsevier, Amsterdam

Fang X, Peng B, Zhang K, Zeng D, Kuang X, Wu B, Tu X, Song Z, Xiao Y, Yang Z (2018) Geochemistry of major and trace elements in sediments from inlets of the Xiangjiang and Yuanjiang River to Dongting Lake, China. Environ Earth Sci 77:1-16

Filella M (2017) Tantalum in the environment. Earth-Science Rev 173: 122-140. https://doi.org/10.1016/j.earscirev.2017.07.002

Folk RL (1980) Petrology of Sedimentary Rocks. Hemphill Pub, Co., Austin

Gaál G, Gorbatschev R (1987) An outline of the Precambrian evolution of the Baltic Shield. Precambrian Res 35(15-52):0301-9268
Gallet S, Jahn B, Lano BVV et al (1998) Composition of the upper continental crust. Earth Planet Sci Lett 56:157-172

Gao S, Luo T, Zhang B, Zhang H, Han Y, Zhao Z, Hu Y (1998) Chemical composition of the continental crust as revealed by studies in East China. Geochim Cosmochim Acta 62:1959-1975. https://doi.org/ 10.1016/S0016-7037(98)00121-5

Ghorbani Y, Fitzpatrick R, Kinchington M, Rollinson G, Hegarty P (2017) A process mineralogy approach to gravity concentration of tantalum bearing minerals. Minerals 7. https://doi.org/10.3390/ $\min 7100194$

Grip E, Wirstam $\AA$ (1970) The Boliden sulphide deposit. A review of geo-investigations carried out during the lifetime of the Boliden mine, Sweden (1924-1967). Sveriges Geologiska Undersökning, Uppsala

Gunn G (ed) (2014) Critical Metals Handbook. Wiley, Oxford

Gustafsson Ö, Widerlund A, Andersson P et al (2000) Colloid dynamics and trasport of major elements through a boreal river-brackish bay mixing zone. Mar Chem 71:1-21

Hall GEM, Vaive JE, Beer R, Hoashi M (1996) Selective leaches revisited, with emphasis on the amorphous Fe oxyhydroxide phase extraction. J Geochem Explor 56:59-78. https://doi.org/10.1016/ 0375-6742(95)00050-X

Hu Z, Gao S (2008) Upper crustal abundances of trace elements: a revision and update. Chem Geol 253:205-221. https://doi.org/10.1016/ j.chemgeo.2008.05.010

Ingri J, Pontér C (1986) Rare earth abundance patterns in ferromanganese concretions from the Gulf of Bothnia and the Barents Sea. Geochim Cosmochim Acta 51:155-161. https://doi.org/10.1016/00167037(87)90016-0

Ingri J, Widerlund A, Suteerasak T, Bauer S, Elming SÅ (2014) Changes in trace metal sedimentation during freshening of a coastal basin. Mar Chem 167:2-12. https://doi.org/10.1016/j.marchem.2014.06. 010

Koschinsky A, Hein JR (2003) Uptake of elements from seawater by ferromanganese crusts : solid-phase associations and seawater speciation. Mar Geol 198:331-351. https://doi.org/10.1016/S00253227(03)00122-1

Land M, Ingri J, Öhlander B (1999a) Past and present weathering rates in northern Sweden. Appl Geochem 14:761-774

Land M, Öhlander B, Ingri J, Thunberg J (1999b) Solid speciation and fractionation of rare earth elements in a spodosol profile from northern Sweden as revealed by sequential extraction. Chem Geol 160: 121-138. https://doi.org/10.1016/S0009-2541(99)00064-9

Melcher F, Graupner T, Gäbler HE, Sitnikova M, Oberthür T, Gerdes A, Badanina E, Chudy T (2017a) Mineralogical and chemical evolution of tantalum-(niobium-tin) mineralisation in pegmatites and granites. Part 2: Worldwide examples (excluding Africa) and an overview of global metallogenetic patterns. Ore Geol Rev 89:946987. https://doi.org/10.1016/j.oregeorev.2016.03.014

Melcher F, Graupner T, Oberthur T, Schutte P (2017b) Tantalum-(niobium-tin) mineralisation in pegmatites and rare-metal granites of Africa. South African J Geol 120:77-100. https://doi.org/10. 25131/gssajg. 120.1.77

Nyström A (2004) Elektronikskrot - den nya koppargruvan. In: Miljö Utveckl. https://miljo-utveckling.se/elektronikskrot-den-nyakoppargruvan/. Accessed 1 Nov 2019

Occupational Safety and Health Administration (OSHA) (2014) Chemical management and permissible exposure limits (PELs). (Report No. 2014-24009). U.S. Department of Labor. https:// www.osha.gov/laws-regs/federalregister/2014-10-10. Accessed 12 Sep 2019

Ödman F, Ruth T, Ponte C (1999) Validation of a field filtration technique for characterization of suspended particulate matter from freshwater. Part I. Major elements. Appl Geochem 14:301-317 
Plank T, Langmuir CH (1998) The chemical composition of subducting sediment and its consequences for the crust and mantle. Chem Geol 145:325-394. https://doi.org/10.1016/S0009-2541(97)00150-2

Rankama K (1944) On the Geochemistry of Tantalum. Government Press, Helsinki

Ray R, Dutta B, Mandal SK, González AG, Pokrovsky OS, Jana TK (2020) Bioaccumulation of vanadium $(\mathrm{V})$, niobium $(\mathrm{Nb})$ and tantalum (Ta) in diverse mangroves of the Indian Sundarbans. Plant Soil 448:553-564

Rodushkin I, Engström E, Baxter DC (2010) Sources of contamination and remedial strategies in the multi-elemental trace analysis laboratory. Anal Bioanal Chem 396:365-377. https://doi.org/10.1007/ s00216-009-3087-z

Rudnick RL, Gao S (2013) Composition of the continental crust, 2nd edn. Elsevier, Amsterdam

Salminen R, Batista MJ, Bidovec M, et al (2005) Nb - Niobium. In: Geochemical Atlas of Europe. Part 1: Background Information, Methodology and Maps. Geological Survey of Finland, Espoo, p 526

Salminen R, Batista MJ, Bidovec M, et al (2004) Ta - Tantalum. In: Geochemical Atlas of Europe. Part 1: Background Information, Methodology and Maps. Geological Survey of Finland, Espoo, p 526

Selway JB, Breaks FW, Tindle AG (2005) A review of rare-element (LiCs-Ta) pegmatite exploration techniques for the superior province, Canada, and large worldwide tantalum deposits. Explor Min Geol 14:1-30. https://doi.org/10.2113/gsemg.14.1-4.1

Snowball I, Sandgren P (2002) Geomagnetic field variations in northern Sweden during the Holocene quantified from varved lake sediments and their implications for cosmogenic nuclide production rates. Holocene 12:517-530

Sobek A, Wiberg K, Sundqvist K, et al (2012) Dioxiner i Bottenhavet och Bottenviken - pågående utsläpp eller historiska synder. Gävleborg

Sohlenius G, Hedenström A (2008) Description of regolith at LaxemarSimpevarp. Report no. R-08-05. Svensk Kärnbränslehantering AB, Stockholm, Sweden
Suteerasak T, Elming SÅ, Possnert G, Ingri J, Widerlund A (2017) Deposition rates and $14 \mathrm{C}$ apparent ages of Holocene sediments in the Bothnian Bay of the Gulf of Bothnia using paleomagnetic dating as a reference. Mar Geol 383:1-13. https://doi.org/10.1016/j. margeo.2016.10.009

Taylor SR, McLennan SM (1985) The Continental Crust: Its Composition and Evolution. Blackwell Scientific Publications, Oxford

Viers J, Dupré B, Gaillardet J (2009) Chemical composition of suspended sediments in World Rivers: New insights from a new database. Sci Total Environ 407:853-868. https://doi.org/10.1016/j.scitotenv. 2008.09.053

Viss (2017) Skelleftehamnsfjärden (Kallholmsfjärden). https://viss. lansstyrelsen.se/Waters.aspx?waterMSCD=WA17311472. Accessed 1 Nov 2019

Voipio A (1981) The Baltic Sea, Elsevier, Amsterdam

Widerlund A, Ingri J (1996) Redox cycling of iron and manganese in sediments of the Kalix River Estuary, northern Sweden. Aquat Geochem 2:185-201

Widerlund A, Roos P (1994) Varved sediments in the Kalix River estuary, northern Sweden. Aqua Fenn 24:163-170

Windom HL, Schropp SJ, Calder FD, Ryan JD, Smith RG, Burney LC, Lewis FG, Rawlinson CH (1989) Natural trace metal concentrations in estuarine and coastal marine sediments of the southeastern United States. Environ Sci Technol 23:314-320

Xiao Y, Sun W, Hoefs J, Simon K, Zhang Z, Li S, Hofmann AW (2006) Making continental crust through slab melting: Constraints from niobium-tantalum fractionation in UHP metamorphic rutile. Geochim Cosmochim Acta 70:4770-4782. https://doi.org/10. 1016/j.gca.2006.07.010

Publisher's note Springer Nature remains neutral with regard to jurisdictional claims in published maps and institutional affiliations. 